\title{
WATER-SUPPLY AQUIFERS AT EAGLE RIVER, ALASKA
}

\author{
By James A. Munter and Roger D. Allely
}

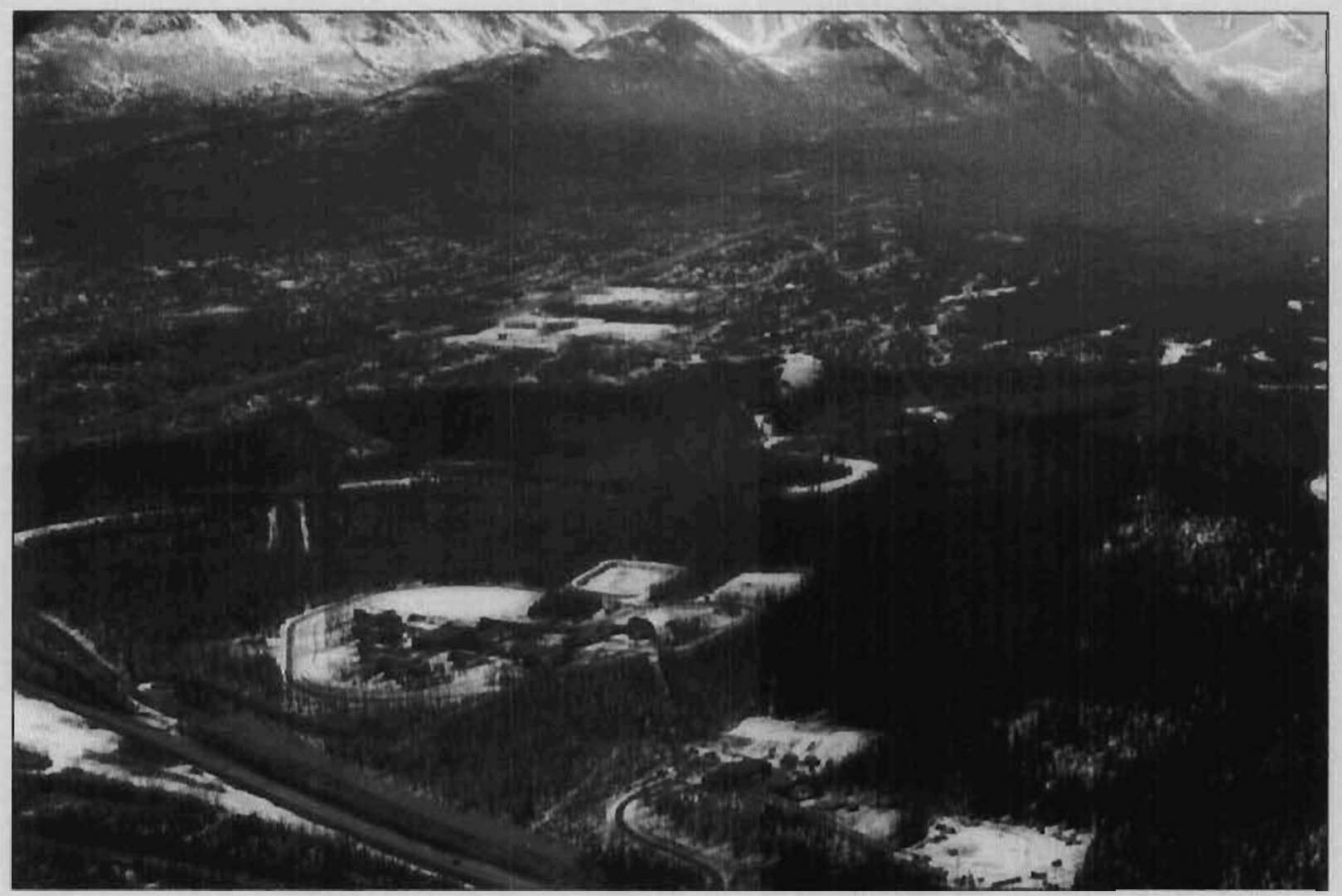

Professional Report 108

Published by

STATE OF ALASKA

DEPARTMENT OF NATURAL RESOURCES

DIVISION OF GEOLOGICAL \& GEOPHYSICAL SURVEYS

In cooperation wilh the Division of Water

Winter 1992

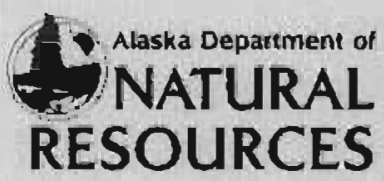




\title{
WATER-SUPPLY AQUIFERS AT EAGLE RIVER, ALASKA
}

\author{
By James A. Munter and Roger D. Allely
}

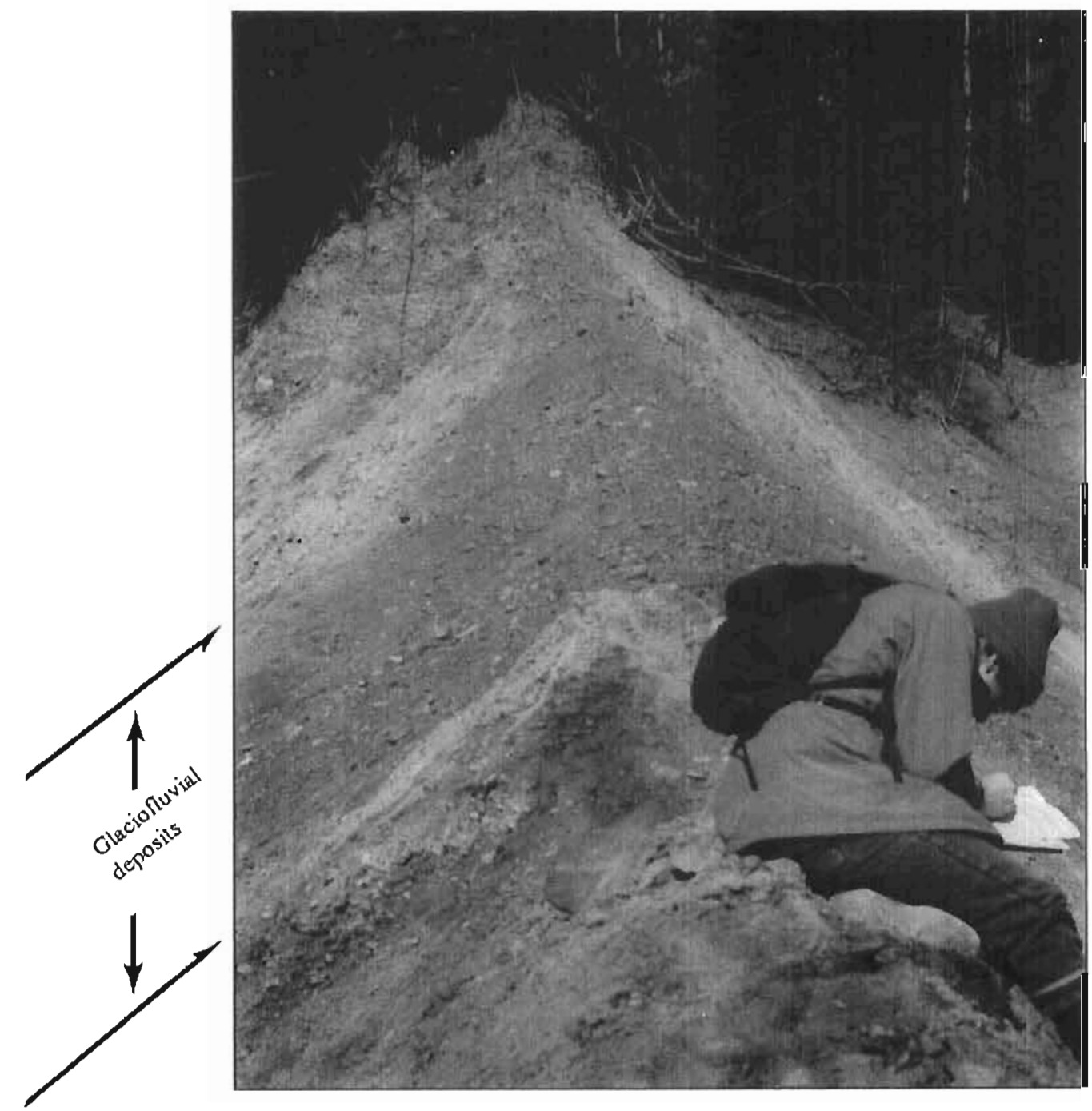

Glaciofluvial deposils of Eagleridge aquifer, overlain by till and underlain by confining unit of silty dianicton. Photo laken at measured-section location (shees I) by Jim Munter.

Cover. Eagle River Midvalley urea, Glenn Highway in foreground. Meadow Creek in background. Phoro by Stan Carrick
Professional Report 108

Division of Geological \&

Geophysical Surveys

Fairbanks, Alaska

Winter 1992 


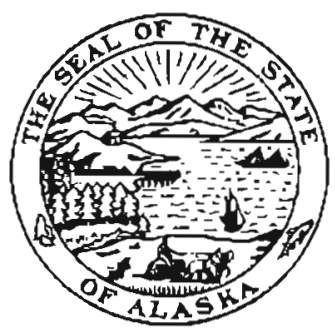

STATE OF ALASKA

Walter J. Hickel, Governor

DEPARTMENT OF NATURAL RESOURCES

Glenn A. Olds, Commissioner

DIVISION OF GEOLOGICAL \& GEOPHYSICAL SURVEYS

Thomas E. Smith, State Geologist

Address mail orders to the Fairbanks office. DGGS publications may be inspected at the following locations.

Alaska Division of Geological \& Geophysical Surveys

794 University Avenue, Suite 200

Pairbanks, Alaska 99709-3645

Department of Natural Resources

Public Information Center

3601 C Street, Suite 200

Anchorage, Alaska 99510

U.S. Geological Survey Earth Science Information Center

Grace Hall, Alaska Pacific University Campus

4230 University Drive, Room 101

Anchorage, Alaska 99508-4664

This publication, seleased by the Division of Geological \& Geophysical Surveys, was produced and printed in Fairbanks, Alaska by Graphics North Printing Co. The oversize shects wore printed in Washinglon, D.C. by Williams \& Keintz. The towat cost for prining was $\$ 13$ per copy. Publication is required by Alaska Statute 41, "to delemine tho potentisl of Alaskan land for production of metals, minersls, fuols, and geothermsl resources; the location and supplies of groundwater and construction materials; the potential geologic hazards to buildings, coads, bridges, and other instsilstions and structures; and shall conduct such other surveys and investigations as will advance knowledge of the geology of Alaska." 


\section{CONTENTS}

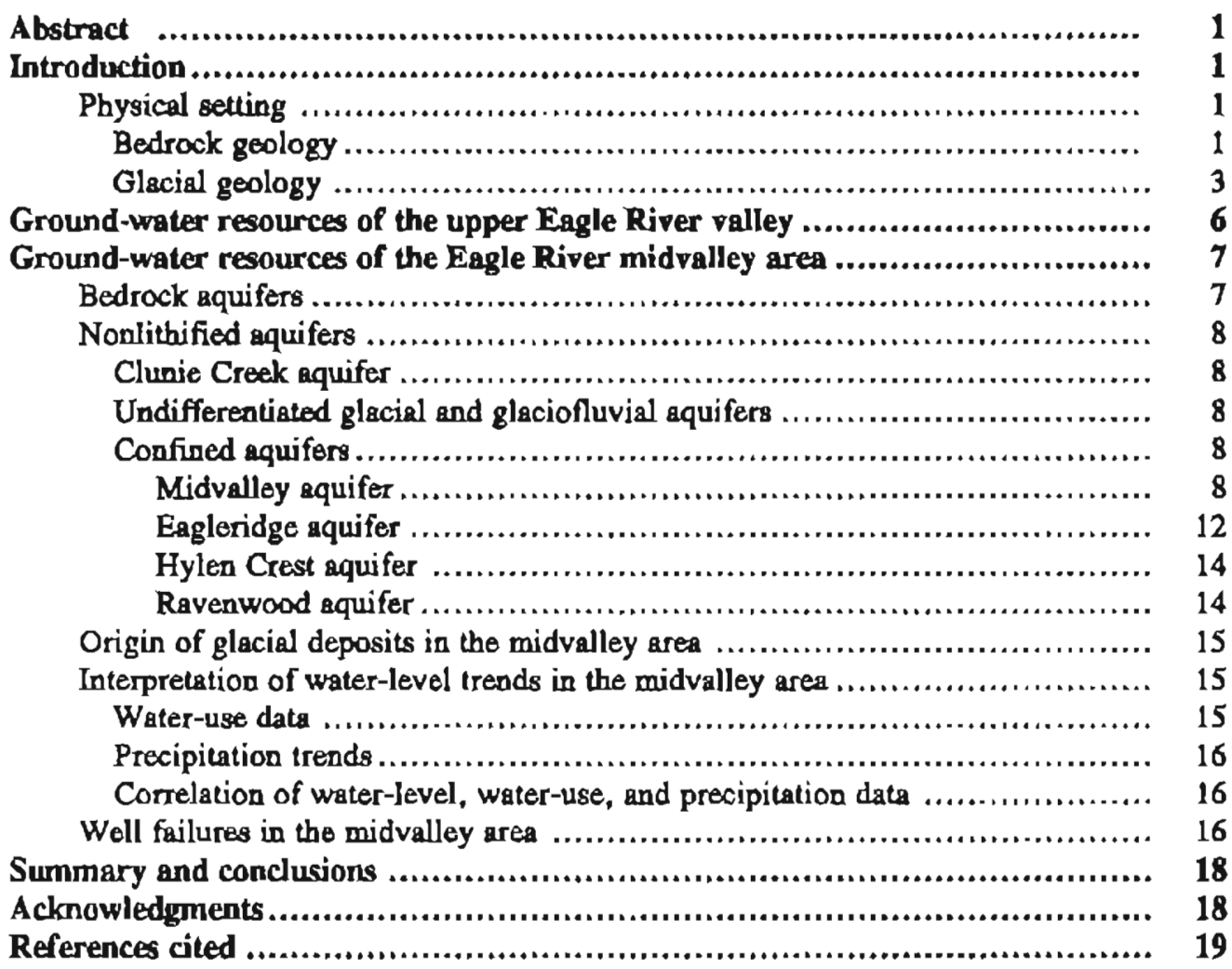

\section{FIGURES}

Figure 1. Location map of the community of Eagle River and the Eagle River drainage area .........................................................

2. Location map of the Bagle River midvalley area with elevations of the top of the bedrock surface in selected deep wells ................ 3

3. Map showing generalized bedrock geology of the Eagle River area ... 4

4. Chart showing comparisons of geologic and hydrogeologic units at Eagle River ................................................. 5

5. Graph of water-level data collected at three wells in Eagle River ...... 13

6. Diagram showing estimated and reported water use in the midvalley area, 1988

7. Graph of water-use data for four major users of confined aquifers in Eagle River, 1983-87

8. Graph of annual precipitation at Anchorage Weather Service Meteorological Office - Airport.

\section{TABLES}

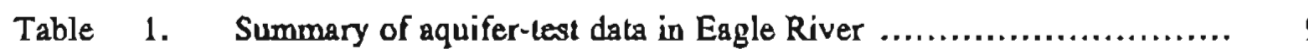

2. List of active class $A$ and class $B$ public water systems using wells in the midvalley area.

3. Lnformation regarding three water-level observation wells in Eagle River 
4. Water-level dats collected at two wells tapping the midvalley

aquifer, Eagle River

\section{SHEETS \\ [In pocket]}

Sheet 1. Thickness of nonlithified deposits and cross sections, Engle River, Alaska

2. Comparison of surface and subsurface stratigraphic date

3. Maps showing structure contours of the bedrock surface and public water system availability (A); and distribution of aquifers and key wells (B)

4. Structure contours and potentionetric surfaces of Eagle River area confined aquifers 


\title{
WATER-SUPPLY AQUTFERS AT EAGLE RIVER, ALASKA
}

\author{
By
}

James A. Munter' and Roger D. Allely ${ }^{\perp}$

\section{ABSTRACT}

Ground water for domestic and commercial use in Eagle River, Alaska, is obtained from both bedrock and nonlithified aquifers. Most of it is obtaincd from confined sand-and-gravel aquifers occurring within glacial, glacio fuvial, and glaciolacustrine sediments up to 700 ft thick. Ground water is also obtained from 8 shallow glacioalluvial aquifer and sedimentary and metamorphic bedrock aquifers. As a result of rapid population growth during the early $1980^{\circ}$ s, the community of Eagle River experienced an increase in ground-water use, synclironous water-level declines in two confined aquifers, and failure of private domestic wells. The water-level doclines and well failures were restrictod to an area within a 1-mi radius of primary production wells tapping the contined aquifers. Although water is currently imported to the most densely developed area of Eagle River from a remote surface water source (Eklutna Lake), most of the Ragie River anea continues to rely on local ground water for residential water supply. In most of thesc areas, ground-water resources are likely to remsin adequate for local water-supply requirements.

\section{INTRODUCTION}

The community of Eagle River, Alaska (fig. 1) grew rapidly during the early 1980's, primarily through residential and light commercial expansion. Growth was initially facilitated by an increased reliance on local ground-water supplies obtained from unconfined and confined sand and gravel aquifers, and bedrock aquifers (Munter, 1984). From 1982 to 1987, ground-water resources in parts of Eagle River were sigaificantly stressed by pumpage, resulting in conflicts over limited water supplies (Munter and Prokosch. 1985) and well failures (Muntex, 1989). During the same period, numerous small independent water systems were consolidated under ownership of the Anchorage Water and Wastewater Utility (AWWU) to improve water service, and surface-water supplies were piped from Ship Creek in Anchorage to Eagle River to supplement local ground-water supplies. Presently (1990), mos developed areas in the Eagle River valley rely on local ground water either from individual domestic wells or from a few privately owned public-supply wells. This report describes aquifers at Eagle River used for ground-water supplies. Information for the report was obtained from stratigraphic test drilling, examining available well records and aquifer test information, collecting water-level data, interviewing well owners, and reviewing relevart bistoric data.

\footnotetext{
Alaska Hydrologic Survey, Division of Water, P.O. Box 772116 , Eagle River. Alaska 99577-2116.
}

For this report the community of Bagle Rives is divided into the upper-valley, midvalley, and lower-valley areas (fig. 1). The upper-valley area, including South Fork Eagle River valley, had a population of 2,323 in 1988 (Muricipality of Anchorage, 1989); water supplies here are almost exclusively obtained from individual domestic wells. The midvalley area (1988 population of 14,106$)$ is where most ground-water problems have occurred; fortunately, it also has the most ground-water data available. The commercial district and some residential neighborhoods in the midvalley area are connected to public water and sewer systerns. The lower valley area is largely unpopulated and consists mostly of Fort Richardson Military Reservation property.

Zenone and others (1974) presented a variety of geologic and ground-water information for the Eagle River area, including numerous chemical analyses of ground water. Natural concentrations of common inorganic constituents were cousistently found to be acceptable for domestic use. Natural-water chemistry is not further addressed in this report.

\section{PHYSICAL SETTING}

The 30-mi-long Eagle River valley is one of the largest valleys in the western Chugach Mountains (fig. 1). Eagle Glacier is the source of Eagle River. The glacier covers 7 percent of the river's $232-\mathrm{mi}^{2}$ drainage area, and numerous small side-valley glaciers cover an additional 5 percent of the basin. The river flows through a 0.5- to 2-mi-wide, U-sbaped glacial valley for about $20 \mathrm{mi}$, then emerges to flow for about 6 mi through glacjated lowlands before entering Knik Arm of Cook Inlet (fig. 2). The largest tributary of Eagle River is South Fork Eagle River, which enters the main stem 9 mi upstream from Xnik Arm. Two small glaciers feed South Fork Eagle River. Meadow Creek, the second largest tributary, is a nonglacier-fed stream that enters Eagle River from the north, near the Glenn Highway.

\section{BEDROCK GEOLOGY}

Both sedimentary and metamorphic rocks are exposed in the Eagle River area. These rocks are overlain by a mantle of ponlithified deposits that is thin to absent in mountainous areas and some lowland localities but up to $700 \mathrm{ft}$ thick in the Eagle River valley. Both sedimentary and metamorphic rocks are termed "bedrock" in this report. 


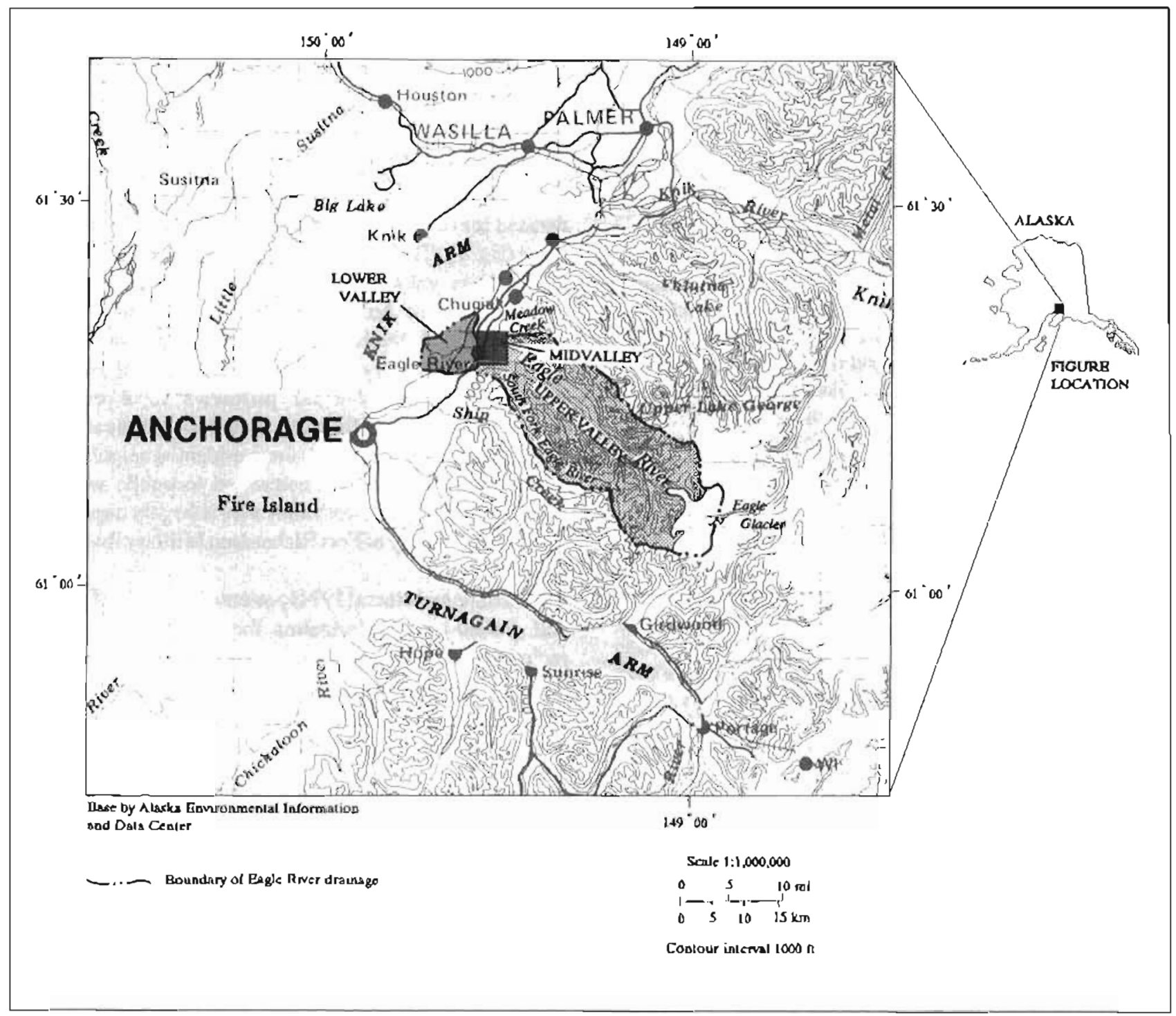

Figure 1. Location map of the community of Eagle River and the Eagle River drainage area.

Rocks of the Chugach Mountains near Eagle River (fig. 3) are metamorphic and consist mostly of the McHugh Complex and the Valdez Group of Mesozoic age (Clark, 1972a; Tysdal and Plafker, 1978). The McHugh Complex consists of a deformed metaclastic sequence (siltstone, graywacke, arkose, conglomeratic sandstone) that is chaotically juxtaposed with a metavolcanic sequeace (greenstones, metachert, cherly argillite, argillite) (Clarke, 1973). The Valdez Group in this area consists mostly of metagraywacke, siltite, and argillite (Clark, 1972a). These Mesozoic rocks at Engle River are bounded on the northwest by the Border Ranges fault zone (MacKevett and Plafker, 1974), which is locally called Knik fault (Clark, 1972a). Plafker and Campbell (1978) describe the Border Ranges fault zone as "a major tectonic boundary in southern Alaska that defines the landward margin of an oceanic accretionary terrane of Mesozoic age. " The Mesozoic rocks have been accreted to an assemblage of Permian to Jurassic rocks that are part of the lithologically diverse Peninsular tectonostratigraphic terrane (Jones and Silberling, 1979; Plafker and others, 1989). Locally, the Permian to Jurassic rocks ure named the Thunderbird Complex and are described by Updike and Ulery (1983). These rocks are exposed only at a few locations in a narrow band along the base of the Chugach Mountains north of Meadow Creek (map unit JPu, fig. 3).

The lowlands near Knik Arm are underlain by Terliary sedimentary rocks, chiefly siltstone, sandstone, and lignite. Wolfe and others (1966) correlated leaf fossils from exposures in the lower Eagle Rivervalley with the Otigocene to Miocene Tyonek Formation of the Kenai Group. The lithology, structure, and juxtaposition of local exposures 


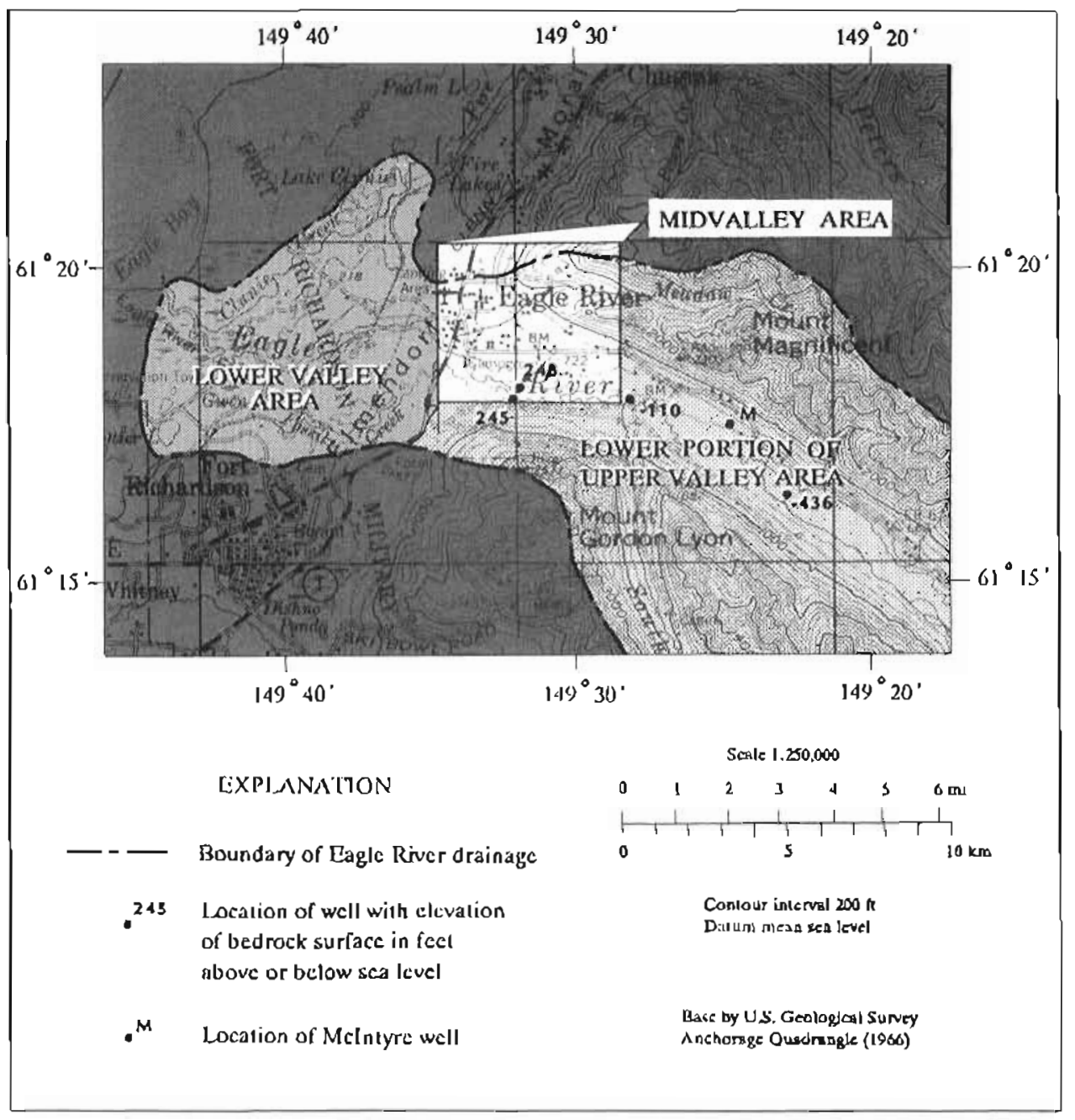

Figure 2. Location map of the Eagle River midvalley area with elevations of the rop of the bedrock surface in selecred deep wells. suggest that the Kenai Group rocks may be faulted against pre-Tertiary rocks, possibly by Tertiary activity of the Border Ranges fault zone.

\section{GLACIAI GEOLOGY}

The Cook Jnlet area has been glaciated numerous times during the Pleistocene (Karlstrom, 1964; Schmoll and Yehle, 1986) and possibly during the late Tertiary (Schmoll and others, 1984). Low mountain nanks near Eagle River are typically manlled with moraines and colluvial deposits, and lowlands are covered with moraines, alluvium, glacioalluvium, lake-bed deposits, and other types of drif (Scbmoll and others, 1980; Yehle and Schmoll, 1989). The occurrence of several different levels of lake-bed erosional features io Eagle Rivec valley (Schmoll and others, 1980; Yehle and Schmoll, 1988; 1989; Yehle and others, 1990) provides evidence that glacier-dammed lakes bave formed repeatedly during the Quaternary history of the valley. Yehle and Schmoll (1989) and Yehle and others (1990) provide additional details of the geologic history of the
Eagle River area. Comparisons of geologic and hydrogeologic units in Eagle River ace shown in figure 4.

The stratigraphy of Quatemary deposits in the midvalley area is significant because numerous public and individual-domeslic water-supply wells occur in that area. Cross sections through the midvalley area show najor hydrostratigraphic units and water-level data (see sheet 1). The cross sections are based on interpretation of well drillers' logs, measurements of static water levels, stratigraphic test drilling, and examination of natural exposures. The following discussion of geologic deposits at Eagle River is presented to provide a framework for the description of aquifers in subsequent sections of the report.

Shoets 1 and 2 present locations and descriptions of measured stratigraphic sections at a bluff along the Eagle River and results of stratigraphic test drilling about $600 \mathrm{ft}$ to the north-nortbeasl. Test drilling was done with an airrotary rig equipped with a drive-through hammer, which allowed 6-in.-diam steel casing to be advanced with the boreboles. The first hole drilled at the site, test hole ER3, 


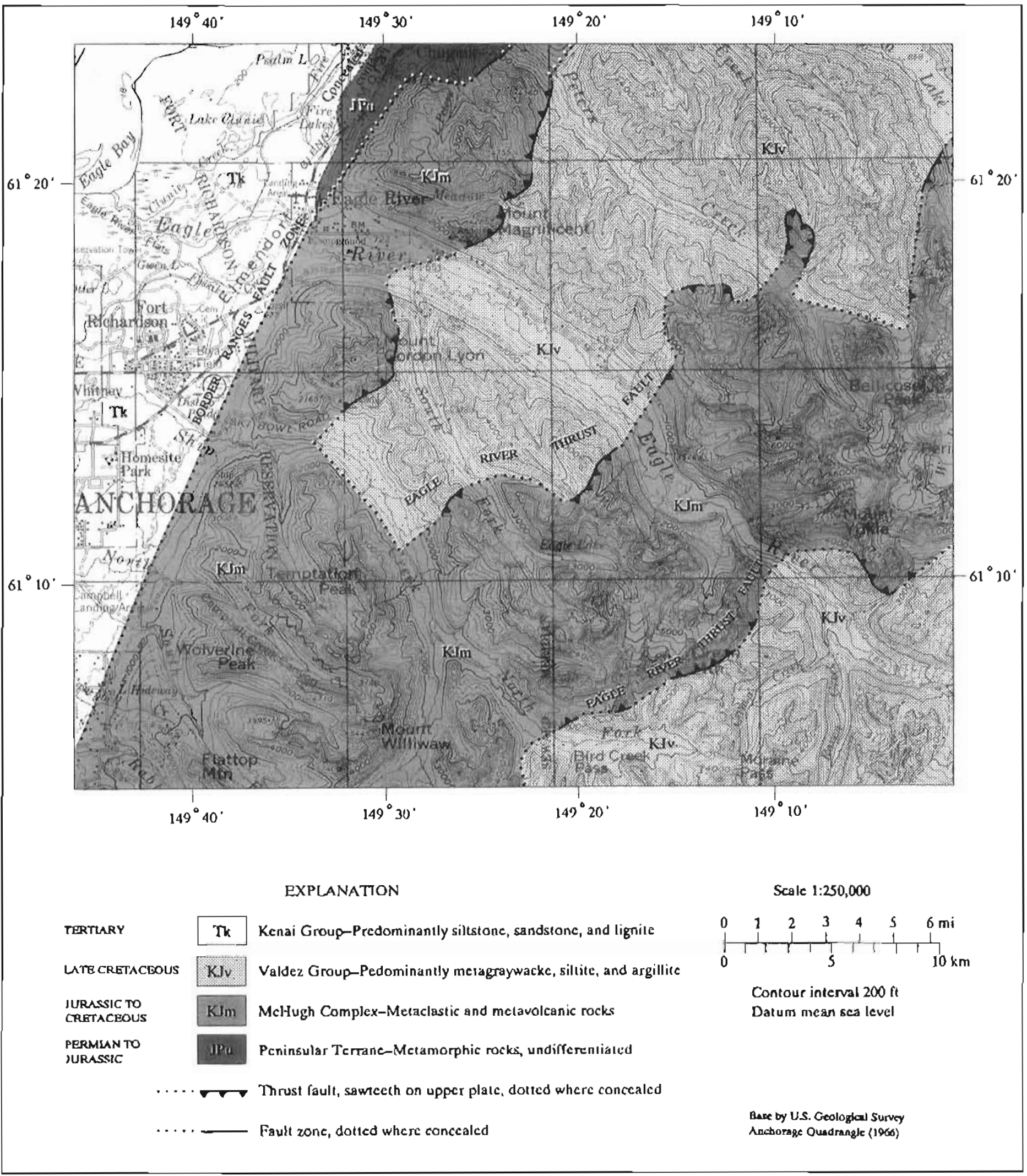

Figure 3. Generalized bedrock geology of the Eagle River area (after Clark, 1972a; and Jones and Silberling, 1979). 
Water-supply Aquirers at Eaglo RIVER, Alaska

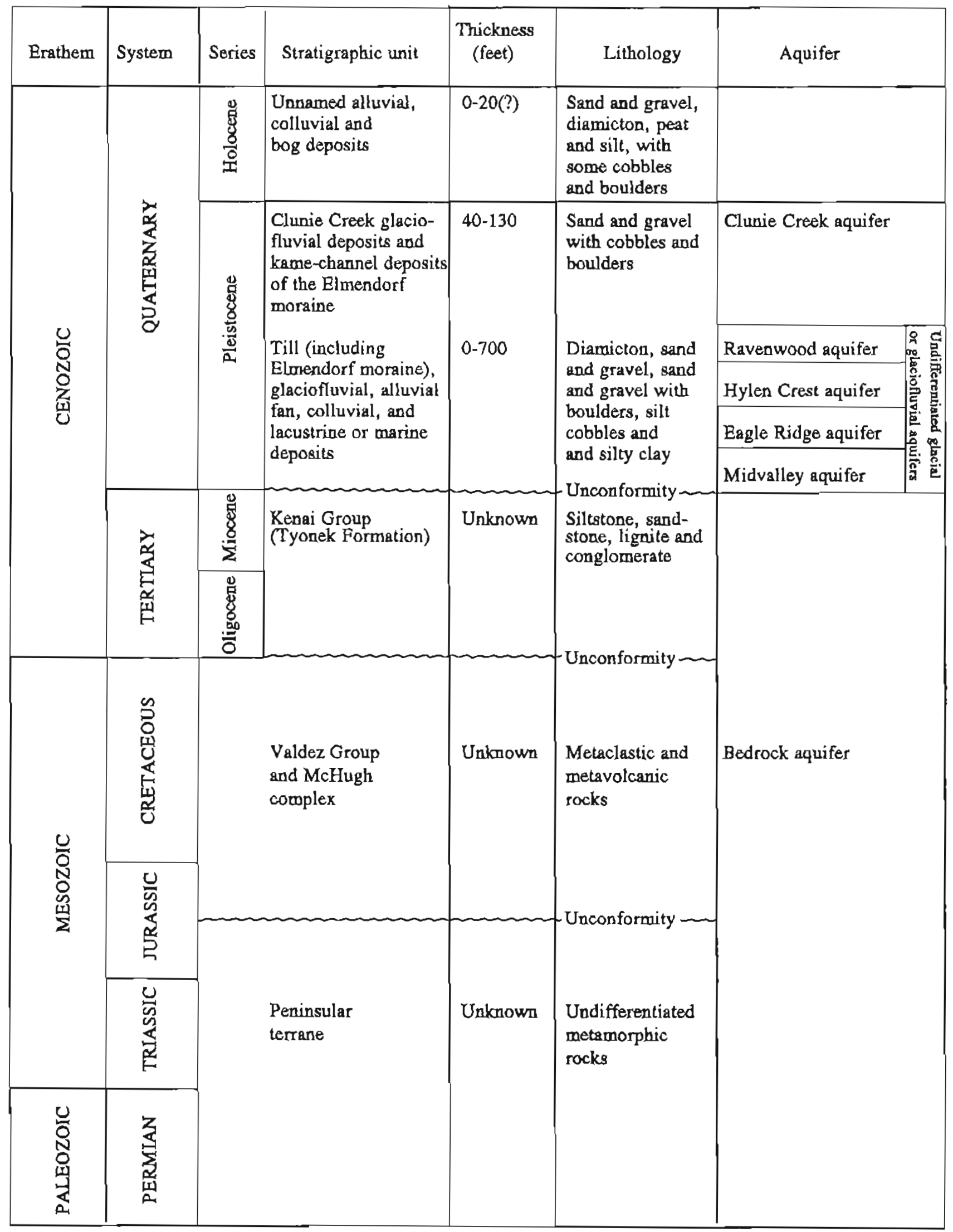

Figure 4. Comparisons of geologic and hydrogeologic units at Eagle River. 
was logged by visual examination of cutting returns and with borehole geophysical instruments (sheet 2). Attempts to set a screen in the hole failed and the hole was subsequently abandoned. Wells ER4S and ER4D, drilled $11 \mathrm{ft}$ northwest of well ER3, were drilled and completed as a dual-completion installation with open intervals from $126 \mathrm{ft}$ to $129 \mathrm{ft}$ below land surface and at $219 \mathrm{ft}$ below land surface, respectively. Well ER5, drilled $10 \mathrm{ft}$ west of well ER3 and $8 \mathrm{ft}$ south of wells ER4S and ER4D, was completed as an observation well with an open interval at a depth of 263 to $268 \mathrm{ft}$ below land surface.

The measured section shown in sheet 2 is divided into three distinct geologic units (youngest to oldest): till, glaciofluvial deposits, and undifferentiated drif.

Mucb of the lowland of the midvalley area is mantled with ground moraines (map unit Qmg, shown by Schmoll and others, 1980) that correlate with the till observed in the measured section (sheet 2). Reger and Updike (1983) assigned an age of late Wisconsinan to surficial deposits of this area, and this age is consistent with the conclusion of Schooll and others (1980) that the upper part of map unit Qng correlates with deposits in the Elmendorf moraine southwest of Eagle River. The Elmendorf moraine is an end moraine caused by the advance of the Koik-Matanuska glacial lobe (Schmoll and others, 1984) during the late stade of the Naptowne Glaciation, which ended approximately 10,000 to 11,000 yr ago (Reger and Updike, 1983). Sheet 1 shows the thickness of nonlithified deposits in the midvalley area. Nonlithified deposits are up to $700 \mathrm{ft}$ thick where the Elmendorf moraine deposits (and older nonlithified deposits) overlie a bedrock low in the eastern part of the nidvalley area.

The glaciofluvial deposits lyjug inmediately beneath the till at the measured section (sheet 2) are interpreted to be advance outwash deposits of the glaciation that produced the Elmendorf moraine. The unit does not correlate with any surficial map units of Schmoll and others (1980) or Yehle and Schmoll (1989), but it does correlate with an advance outwash deposit shown in map and cross-section views by Miller and Dobrovolny (1959) and by Yehle and others (1990) near the mouth of the Eagle River and with an advance outwash unit mentioned by Reger and Updike (1983) near the Glenn Highway bridge over the Eagle River. Karlstrom (1964) also notes the existence of an advance outwash unit under the Elmendorf moraine on the west side of Krik Arm. The till and glaciofluvial deposits observed in the bluff exposure are correlated with sediments observed in the upper $132 \mathrm{ft}$ of test hole ER3. The glaciofluvial deposits are interpreted to be of late Wisconsinan age.

The undifferentiated drift observed at the measured section (sheet 2) consists of sand and sandy gravel units below a silty diamicton. Nearby subsurface data indicate that multiple sand and gravel units occur within a sequence of sandy and gravelly silt units. In places, the sand and gravel units are $20 \mathrm{ft}$ or more thick. Schmoll and others (1980) mapped this outcrop of drift and a similar exposure located $1 \mathrm{mi}$ northwest as interglacial pond deposits. Sediments from that exposure, which may correlate with the drift observed in the measured section, were radiocarbondaled as older than 38,000 yr B.P. (Marsters and others, 1969), which is older than the overlying Elmendorf moraine and advance outwash deposits. The thickness, lithology, and extent of the undifferentiated drift deposits described in this report indicate that at least part or possibly all of the unit results from lacustrine or marine deposition and subaqueous proglacial delta or outwash deposition. In the absence of more detailed information. the undifferentiated drift is assigned an age of pre-late Wisconsinan for this report.

The undifferentiated drift unit described in sheet 2 may correlate with thick accumulations of silly sediment observed in the subsurface east of the measured section (Dearborn, 1977; CH2M Hill, 198^; Deeter and George, 1982). The sediments at the measured section differ significantly from their eastern counterparts by showing a much greater proportion of sands and gravels. The higher percentage of sands and gravels in the midvalley areas compared to the upper-valley areas may be attributable to active sedimentation occurring near the confluence of four glacial valleys (Knik Arm, Eagle River, Meadow Creek, South Fork Eagle River) in the midvalley area, rather than quiet-water lacustrine or maripe deposition farther upval ley.

\section{GROUND-WATER RESOURCES OF THE UPPER EAGLE RIVER VALLEY}

A series of water-resource investigations have used geophysics, low-flow investigations, and test drilling to characterize ground-water supply potential in the upper Eagle Rjver valley (Dearborn, 1977; R\&M Consultants, 1979; Dearbom and Schaefer, 1981; CH2M Hill, 1981; Deeter and George, 1982; Smith and Robertson \&Associates, 1983). Although the metamorphic bedrock surface is well below present-day sea level in the upper valley, most of the valley-fill sediments are silty, and no prolific valleywide aquifers have been discovered. Most residents of the area obtain water from metamorphic bedrock aquifers or sandand-gravel aquifers located on the flanks of the Eagle River or South Fork Eagle River valleys. These aquifers have not been studied. L.L. Dearboro (U.S. Geological Survey, written commun., 1980) observed that most of the upper valley sediments apparently consist of silty lacustrine or marine sediments, but that valley-marginal alluvial fans could be siguificant aquifers.

One such valley-marginal slluvial fan, at the Mclntyre location (fig. 2), may bave significant potential groundwater resources. A well drilled May 21, 1982, reportedly 
penetrated "blue clay" from 52 to 121 ft below land surface and yielded $500 \mathrm{gal} / \mathrm{min}$ of water from "sand, gravel, and water" that occurs ut a depth of $125 \mathrm{ft}$ to $134 \mathrm{ft}$. The original static water level was reported to be more than 21 ft above land surface (C.J. Míclntyre, oral commun., 1982). During a field visit by DGGS on June 2, 1982, several springs were noted near the well, some of which may have been created as a result of well driling. An attempt to set a screen in the well failed, and the soil within a 30-ft radius around the casing suddenly collapsed, causing the drilling rig to tip into the resulting bole. The rig and well casing were removed and the hole was filled with $700 \mathrm{yd}^{3}$ of gravelly fill (C.J. McIntyre, oral commun., 1985). A second well was drilled to a depth of $134 \mathrm{ft}$ at the same location (possibly in the same borebole) during January and February 1983 and had a reported artesian flow rate of $160 \mathrm{gal} / \mathrm{min}$ and an estimated well yield of $450 \mathrm{gal} / \mathrm{min}$. As of 1989 , no aquifer testing had been performed at the MeIntyre location to assess the developable capacity of this alluvial fan aquifer (D. Tubbs, Eklutna, Inc., oral commun., 1989).

\section{GROUND-WATER RESOURCES OF THE EAGLE RIVER MIDVALLEY AREA}

A $10.5-\mathrm{mi}^{2}$ area near the confluence of Meadow Creek and the Eagle River, herein termed the "midvalley" area, bas been the focus of population and light commercial growth in Eagle River. The estimated population of the area nearly doubled (from 7,536 to 13,687) between 1981 and 1985 (A. Van Domelen, the Municipality of Anchorage, written commun., 1983, 1984, 1988) and increased to 14,106 in 1988 (Municipality of Anchorage, 1989). Development of now subdivisions was accompanied by construction and expansion of numerous public water supply systems that relied completely on local ground-water sources. About 1,000 to 1,500 single-family residential wells were in use in the midvalley area in 1983 (Munter, 1984).

Johnson (1979) listed 361 wells located within the midvalley area and gave well locations resolved to the fourth-order aliquot parcel (2.5 acres) of the occupied section of laad. However, many assigned locations were incorrect because most wells had not been field located or had been field located before detailed maps of the area became available. Many additional well logs were acquired from other agencies, drillers, and the public during this investigation. An extensive field-and office-location and verification effort was conducted for both previously listed wells and those for which new records were acquired. As of June 9, 1988, the U.S. Geological Survey's WATSTORE database, managed cooperatively in Alaska with DGGS, contained 957 sites with ground-water data. The vast majority of data are from water-well logs, which ustually contain the driller's descriptions of geologic materials penetrated, a static water level, well yield, and well construction information. Numerous unpublished engireering reports describing local well and water-supply systems were also reviewed for this study. Land-surface elevations at most wells were obtained from Municipality of Anchorage L:2,400-scale maps with 4-ft contour intervals.

\section{BEDROCK AQUIFERS}

Bedrock in the midvalley area consists of Tertiary sedimentary rocks and pre-Tertiary metamorphic rocks. The distribution of these two rock types and contours of the bedrock surface are shown in sheet 3 . Sheet 3 also shows areas where most wells obtain water from bedrock. Some wells in these areas obtain water from thin sand and gravel deposits overlying bedrock. In the northwest part of the area, near-surface sedimentary bedrock is not widely used as an aquifer because public water supplies are available; also, wells drilled in the area commonly bad low reported yields (less than $3 \mathrm{gal} / \mathrm{min}$ ).

Bedrock is used extensively as an aquifer north of Meadow Creek and Eagle River Loop Road and east of gravel pits on Eagle River Loop Road (sheet 3). In a study of this area, Petrik (1986) found numerous low-yield wells and local water-shortage problems caused by the low primary and secondary permeability of the fractured metamorphic-rock aquifer. Reported yields of wells varied from 0.1 to $21 \mathrm{gal} / \mathrm{min}$. The median well depth was $277 \mathrm{ft}$ and the median reported well yield was $2 \mathrm{gal} / \mathrm{min}$, the same yield as reported by Johnson (1979) for all wells obtaining water from bedrock in the Chugiak-Eaglo River area. Public water supplies have not been extended to Petrik's (1986) study area.

Eighteen of 53 wells studied by Petrik (1986) had reported yields of $1 \mathrm{gal} / \mathrm{min}$ or less. A $1-\mathrm{gal} / \mathrm{min}$ yield can supply up to $1,400 \mathrm{gal} / \mathrm{day}$, which is two to five times the amount of water used by most families. However, watersupply problems can occur in these wells when short-term demand-(household pumps may deliver about $7 \mathrm{gal} / \mathrm{min}$ )-exhausts the water available in storage. Under static conditions, the 18 wells described above held 40 to $400 \mathrm{ft}$ ( 60 to $600 \mathrm{gal}$ ) of water in their well bores. Some bouses may also have had supplemental storage tanks, commonly holding 500 gal. Individual water-shortage problems were most commonly addressed by conserving water, distributing water-use activities throughout the day, deepening wells, drilling new wells, installing supplemental storage tanks, or fracturing aquifers by use of explosives or high bydraulic pressures to enhance well yields. These practices are necessitated by the naturally low permeability of the bedrock aquifer encountered at many well sites. Three separate areas totalling 28 acres were ideatified where reported well yields were less than $1 \mathrm{gal} / \mathrm{min}$ (sheet 3). The well data collected also showed an inverse relationship betwoen well depth and well yield. 
Deeper wells, for example, typically had lower yields. This suggests that attempts to increase water yield by deepening a well might be less effective than redrilling at another location. Large differences in the altitude of measured water levels in closely spaced wells prevented identification of an areawide flow system in the bedrock aquifer. This was interpreted to be the result of low bydraulic connectivity of the fractures in the bedrock squifer.

\section{NONLITHIFIED AQUIFERS}

Most ground water in the midvalley aren is obtained from glacial and glaciofluvial deposits of Quaternary age that mandle most of the low-altitude areas of Eagle River. Available data from test drilling and well logs, stratigraphic exposures along the Eagle River, and surficial geologic maps (Schmoll and others, 1971; Schmoll and others, 1980; and Yehle and Schmoll, 1989) are detailed enough to allow delineation of: (1) a shallow glacioalluvial aquifer; (2) undifferentiated glacial or glacionluvial aquifers; and (3) confined sand and gravel aquifers (sheet 3).

\section{CLUNIE CREEK AQULFER}

The Clunie Creek aquifer ranges in thickness from about 40 to about $130 \mathrm{ft}$ and consists mainly of sand and gravel in glacioalluvial channels deposited during the waning phase of the last glaciation. The Clunie Creek aquifer is named after the Clunie Creek glacioalluvial deposits described by Yehle and Schmoll (1989). Areas where most wells obtain water from the Clunie Creek aquifer are shown in sheet 3 . Although glacioalluvial and alluvial deposits occur at land surface more widely than is shown in sheet 3 , they are commonly too thin to be useful as water-supply aquifers. Three calculated transmissivity values for this aquifer range from 11,000 to $110,000 \mathrm{ft}^{2} / \mathrm{day}$ (table 1). Table 2 lists six public water supply systems that tap this aquifer. As a result of inefficiencies associated with keeping numerous small-capacity (up to a few humdred gallons per minute) wells functioning and concerns about contamination of the shallow aquifer, the Muaicipality of Anchorage has largely replaced local ground-water production from the Clunie Creek aquifer with imported surface water (Anchorage Water and Wastewater Utility, written commun., 1984-89). Although additional water supplies could probably be developed from shallow aquifers in the area (Munter, 1984), well locations would require car eful selection 10 avoid groundwater contamination by nitrates and fecal coliform bacteria. Shallow ground-water contamination has been documented on Juanita Street and just north of Farm Avenue (Munter and Maynard, 1987; Municipality of Anchorage, written commun., 1987).

\section{UNDIFFERENTIATED GLACIAL AND GLACIOFLUVIAL AQUIFERS}

Ground water in the midvalley area is also obtained from undifferentiated glacial or glaciofluvial aquifers. These aquifers occur throughout the glaciated lowland where the Clunie Creek aquifer or confined sand and gravel aquifers are not separately mapped and where the mupped depth to bedrock is greater than $50 \mathrm{ft}$. The sand and gravel aquifers are typically small and discontinuous and are commonly confined by till or bedrock or both. Aquifer depths range from abrout $40 \mathrm{ft}$ to several buadred foet. Although reported well yields are commonly low (below $10 \mathrm{gal} / \mathrm{min}$ ), an exceptionally productive glaciofluvial aquifer occurs south of the Eagle River (well 1-14 in $s e x$. 13, T. 14 N., R. 2 W.), where an aquifer estimated to be able to produce more than $180 \mathrm{gal} / \mathrm{min}$ has been reported (H4M Corp., 1986). The top of the sand-and-gravel aquifer occurs at a depth of $254 \mathrm{ft}$ and it is at least $78 \mathrm{ft}$ thick. Drilling stopped before the bottom of the aquifer was penetrated. Two calculated transnissivity values for the undifferentiated glacial and glaciofluvial aquifers are 68 and 2,500 $\mathrm{ft}^{2}$ /day (table 1), which illustrates the wide variability of aquifer potential. Table 2 lists three public water supply systemas obtaining water from the undifferentiated glacial and glaciofluvial aquifer.

\section{CONFINED AQUTFERS}

Lithologic data from about 390 logs of wells tapping confined sand-and-gravel aquifers in the midvalley area are available. Most of these wells tap one of four mappable aquifers ranging in area from 0.26 to $2.27 \mathrm{~min}^{2}$ (sheet 4). Physical characteristics of each of these confined aquifers are described below.

\section{Midralley Aquifer}

The midvalley aquifer is informally named for its central location in the Eagle River valley and consists of multiple sandy and gravelly units of varying lateral continuity. The units are confined above and below by silly sediments of the undifferentiated drift (sheet 2) and its lateral equivalents or by bedrock. Both the "middle" and "lower" aquifers discussed by Munter (1984) are included in the midvalley aquifer of this report because water-level data from wells ER5 ("lower" aquifer) and ER4D ("middle" aquifer) have shown that these aquifers respond almost identically to nesirby pumping stresses.

Structure contours of the top of the midvalley aquifer show that the surface generally slopes from north to south, southwest, and southeast (sheet 4). Logs of seven weils that fully penetrate the aquifer show that the cumulative thickness 


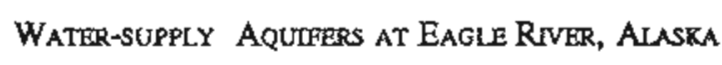

\begin{tabular}{|c|c|c|c|c|c|c|c|c|c|c|c|}
\hline $\begin{array}{l}\text { Pumped- } \\
\text { well } \\
\text { identifier }\end{array}$ & $\begin{array}{l}\text { Test } \\
\text { dates }\end{array}$ & $\begin{array}{c}\text { Duration } \\
\text { of } \\
\text { pumping } \\
\text { (hrs) } \\
\end{array}$ & $\begin{array}{c}\text { Average } \\
\text { pumping } \\
\text { rate } \\
\text { (gal/min) } \\
\end{array}$ & $\begin{array}{l}\text { Observation } \\
\text { wells }\end{array}$ & $\begin{array}{l}\text { Aquifer } \\
\text { tapped }\end{array}$ & $\begin{array}{c}\text { Calculated } \\
\text { trans- } \\
\text { missivity } \\
\left(\mathrm{ft}^{2} / \mathrm{day}\right) \\
\end{array}$ & $\begin{array}{l}\text { Calculated } \\
\text { storativity }\end{array}$ & $\begin{array}{c}\text { Analytical method } \\
\text { used }\end{array}$ & $\begin{array}{c}\text { Source of } \\
\text { data }\end{array}$ & $\begin{array}{c}\text { Aquifer } \\
\text { thickness } \\
\text { penetrated } \\
\text { (ft) } \\
\end{array}$ & $\begin{array}{l}\text { Thickness } \\
\text { screened or } \\
\text { perforated } \\
\text { (ft) } \\
\end{array}$ \\
\hline $2-75$ & $11 / 20 / 71$ & 12.0 & 50 & 0 & Midvalley & 80 & - & $\begin{array}{l}\text { Cooper \& Jacob } \\
(1946)\end{array}$ & $\begin{array}{l}\text { Yones \& Young } \\
\text { Drilling Co. }\end{array}$ & 17 & 8 \\
\hline $1-76$ & $\begin{array}{l}10 / 4 / 78- \\
10 / 7 / 78\end{array}$ & 72 & 165 & 0 & Midvalley & $3,600^{1}$ & - & $\begin{array}{l}\text { Cooper \& Jacob } \\
(1946)\end{array}$ & $\begin{array}{l}\text { R \& M Consultants } \\
(1979)\end{array}$ & 61 & 26 \\
\hline $2-15$ & $\begin{array}{l}11 / 15 / 78- \\
11 / 18 / 78\end{array}$ & 72 & 475 & 1 & Midvalley & 2,200 & $4 \times 10^{-3}$ & $\begin{array}{l}\text { Cooper \& Jacob } \\
(1946)\end{array}$ & $\begin{array}{l}\text { W.C. Ellis, Los } \\
\text { Altos, CA; written } \\
\text { commun., } 1978\end{array}$ & 36 & 28 \\
\hline $2-4$ & $\begin{array}{l}8 / 19 / 82- \\
8 / 20 / 82\end{array}$ & 24 & 295 & 0 & Midvalley & 680 & - & $\begin{array}{l}\text { Cooper \& } J_{a c o b} \\
(1946)\end{array}$ & $\begin{array}{l}\text { CH2M Hill, } \\
\text { Anchorage, AK }\end{array}$ & 18 & 16 \\
\hline $2-76$ & $\begin{array}{l}10 / 12 / 83- \\
10 / 13 / 83\end{array}$ & 36 & 125 & 2 & Midvalley & $330^{\prime}$ & $1 \times 10^{-3}$ & $\begin{array}{l}\text { Cooper \& Jacob } \\
(1946)\end{array}$ & $\begin{array}{l}\text { Smith, Robertson } \\
\text { and Assoc. (1983) }\end{array}$ & 129 & 63 \\
\hline $1-14$ & $\begin{array}{l}6 / 11 / 86- \\
6 / 14 / 86\end{array}$ & 72.5 & 180 & 3 & $\begin{array}{l}\text { Undifferentiated } \\
\text { glaciofluvial }\end{array}$ & 2,500 & $1.5 \times 10^{-4}$ & Theis (1935) & $\begin{array}{l}\text { H4M Corporation } \\
(1986)\end{array}$ & 88 & 15 \\
\hline $1-4$ & $\begin{array}{l}7 / 7 / 81- \\
7 / 8 / 81\end{array}$ & 21.6 & 104 & 0 & Eagle Ridge & 800 & - & $\begin{array}{l}\text { Cooper \& Jacob } \\
\text { (1946) }\end{array}$ & CH2M Hill & 10.5 & - \\
\hline $1-5$ & $\begin{array}{l}8 / 10 / 81- \\
8 / 11 / 81\end{array}$ & 24 & 240 & $i$ & Eagle Ridge & 2,600 & $6 \times 10^{3}$ & $\begin{array}{l}\text { Cooper \& Jacob } \\
\text { (1946) }\end{array}$ & CH2M Hill & 19 & 14 \\
\hline $1-6$ & $\begin{array}{l}12 / 1 / 82- \\
12 / 2 / 82\end{array}$ & 24 & 31 & 0 & Eagle Ridge & 200 & - & $\begin{array}{l}\text { Cooper \& Jacob } \\
\text { (1946) }\end{array}$ & CH2M Hill & 23 & 21 \\
\hline $1-29$ & $\begin{array}{l}3 / 9 / 83- \\
3 / 10 / 83\end{array}$ & 24 & 20 & 0 & Hylen Crest & 47 & - & $\begin{array}{l}\text { Cooper \& Jacob } \\
\text { (1946) }\end{array}$ & $\begin{array}{l}\text { Dowl Engineers, } \\
\text { Anchorage, AK }\end{array}$ & 14 & 10.5 \\
\hline RAV & $3 / 26 / 83$ & 3.1 & 15 & 0 & Ravenwood & 40 & - & $\begin{array}{l}\text { Cooper \& Jacob } \\
(1946)\end{array}$ & $\begin{array}{l}\text { Dowl Engineers, } \\
\text { Anchorage, AK }\end{array}$ & 22 & 10 \\
\hline 2.65 & $6 / 27 / 83$ & 1 & 110 & 0 & Clunie Creek & 19,000 & - & $\begin{array}{l}\text { Cooper \& Jacob } \\
\text { (1946) }\end{array}$ & $\begin{array}{l}\text { Anchorage Water \& } \\
\text { Wastewater Utility }\end{array}$ & 16 & 10.5 \\
\hline $2-41$ & $\begin{array}{l}6 / 11 / 82- \\
6 / 13 / 82\end{array}$ & 58.5 & 474 & 1 & Clunie Creek & $110,000^{1}$ & - & $\begin{array}{l}\text { Theis }(1935) \\
\text { Neuman (1974) }\end{array}$ & $\begin{array}{l}\text { Munter \& Dearborn } \\
\text { (1984) }\end{array}$ & 50 & 15 \\
\hline $2-83$ & $8 / 23 / 82$ & 8.3 & 50 & 2 & Clunie Creek & 11,000 & - & Theis (1935) & DGGS & 49 & 35 \\
\hline $4-25$ & $8 / 4 / 83$ & 12 & 29 & 0 & $\begin{array}{l}\text { Undifferentiated } \\
\text { glaciofluvial }\end{array}$ & 68 & - & $\begin{array}{l}\text { Cooper \& Jacob } \\
(1946)\end{array}$ & $\begin{array}{l}\text { Dowl Engineers, } \\
\text { Anchorage, AK }\end{array}$ & 12 & 10 \\
\hline
\end{tabular}


Table 2. List of active class $A$ and class $B$ public water systems using wells in the midvalley area as extracted from Alaska's Public Water System Tnventory (K.L. Lindley, Alaska Deparment of Envinanmental Conservation, written commun., 1989). See sheet 3 for locations of well map numbers

\begin{tabular}{|c|c|}
\hline Map no. & T-R-S \\
\hline $1-65$ & 14-1-7 \\
\hline $2-8,3-8$ & $14-2-14$ \\
\hline $1-9$ & $14-2-12$ \\
\hline $3-45$ & $14-2-2$ \\
\hline $\mathrm{ECM}$ & $14-2-1$ \\
\hline $1-4,1-5,1-6$ & $14-2-13$ \\
\hline $2-4$ & $14-2-13$ \\
\hline $3-63$ & $14-2-12$ \\
\hline $1-24,2-24$ & $14-1-8$ \\
\hline $12-139,12-239$ & $14-2-12$ \\
\hline $1-39,2-39$ & $14-2-2$ \\
\hline $1-41,2-41$ & $142-2$ \\
\hline MOA-3 & $14-2-11$ \\
\hline $2-83$ & $14-2-12$ \\
\hline $5-83$ & $14-2-12$ \\
\hline $1-56,2-56$ & $14-2-12$ \\
\hline $2-65$ & $14-2-1$ \\
\hline $1-36,2-36$ & $14-2-12$ \\
\hline $1-75,2-75$ & $14-2-12$ \\
\hline $1-69,2-69$ & $14-1-7$ \\
\hline $1-15,2-15$ & $14-1-7$ \\
\hline $2-16$ & 14-2-1 \\
\hline $4-14$ & $142-1$ \\
\hline TV & $14-2-1$ \\
\hline $1-29$ & $14-1-17$ \\
\hline GD & $14-2-11$ \\
\hline $1-60$ & $14-1-7$ \\
\hline
\end{tabular}

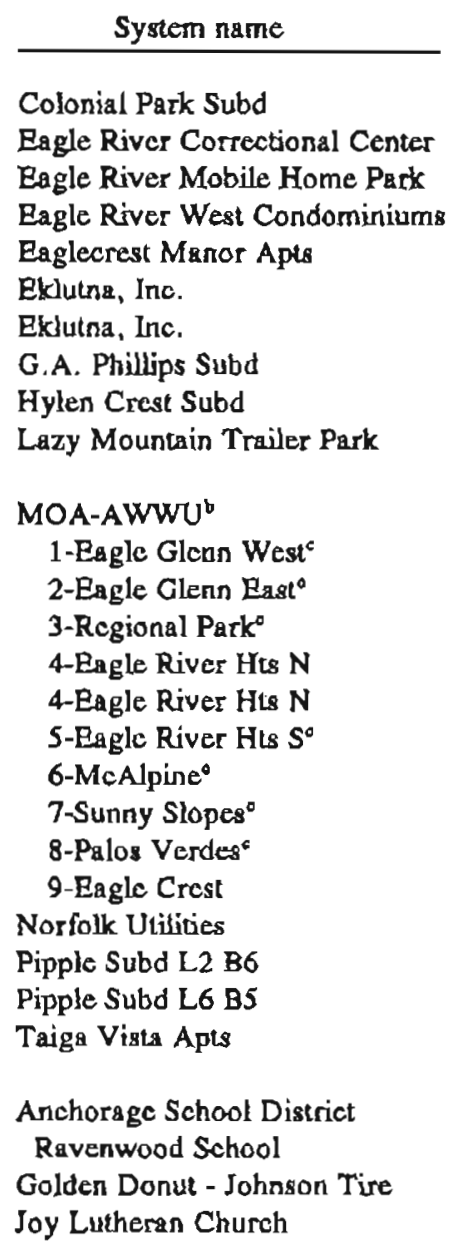

\begin{tabular}{l} 
Class \\
\hline A \\
A \\
A \\
A \\
A \\
A \\
A \\
A \\
A \\
A
\end{tabular}

\begin{tabular}{l}
\multicolumn{1}{c}{ Aquifer tapped } \\
\hline Midvalley \\
Undifferentiated glaciofluvial \\
Midvalley \\
Clunie Creek \\
Unimown \\
Eagleridge \\
Midvalley \\
Midvalley \\
Hylen Crest \\
Midvalley
\end{tabular}

A Clunie Creek

A Clunie Creek

A Clunie Creek

A Undifferentiated glaoiofluvial

A Midvalley

A Midvalley

A Clunie Creek

A Midvaliey

A Midvalley

A Midvalley

A Midvalley

A Midvalley

A Midvalley

A Midvalley

Anchorage School District

Golden Donut - Johnson Tire

Joy Lutheran Church

Township-Range-Section.

Municipality of Anchorage - Anchorage Water and Wastowater Utility.

Welts permanenty deactivated, 1986-88.

of dominantly sand and gravel units in the aquifer ranges from 21 to $117 \mathrm{ft}$ and averages $61 \mathrm{ft}$. Comparison of sheet 4 to sheet 3 shows that the total aquifer thickness (including interbedded fine-grained materials) is commonly 100 to $200 \mathrm{ft}$.

The midvalley aquifer is one of the most prolific and widely used aquifers in Eagle River. Aquifer test data and well production records (Petrik, 1990, 1991a, 199 1b) show that sustainable well yields of 100 to $500 \mathrm{gal} / \mathrm{min}$ are possible in some areas. Most domestic wells completed in this aquifer are open-ended 6-in.-diam casings and have reported yields of 5 to $30 \mathrm{gal} / \mathrm{min}$. The median reported yield of all wells tapping the midvalley aquifer is $17 \mathrm{gal} / \mathrm{min}$. Five calculated transmissivity values for the aquifer range from 80 to $3,600 \mathrm{ft}^{2} /$ day (table 1). Fourteen public water supply systems (table 2) obtain water from the midvalley acquifer.

Continuous water-level data have been collected from a well completed in the midvalley aquifer (well ER5, sheets 1 and 3; table 3) since 1983. The bydrograph (fig. 5) shows that water levels declined 22 ft from early 1983 to mid-1986 and increased about 19 ft from mid1986 to late 1989. The well exhibited large (7-9 ft) shortterm (hours to days) fluctuations of water levels after October 1, 1985, when a 208 -ft-deep public-supply well (well 2-4, sheet 3) located $0.25 \mathrm{mi}$ to the west began operation (Craig Walker, Ekdutna Utilities, Inc., oral commun., 1985). 
Table 3. Informarion regarding three water-level observation wells in Eagle River

Well RAV (Rgvenwood School well 1)

Location: NW1/4 NE1/4 SW1/4 NW1/4 Sec. 17, T. 14 N., R. 1 W., Seward Meridian

Aquifor tapped: Ravenwood aquifer (Quaternary)

Owner: Anchorage School District

Well characteristics: Diameter 6 in.; depth $44 \mathrm{ft}$; open from 43 to $44 \mathrm{f}$

Land surface altitude: $666 \mathrm{ft}$ (determined from 1:2,400-8cale topographic map).

\section{Well ER4S}

Location: NE1/4 NE1/4 NE1/4 NE1/4 Sec. 13, T. 14 N. R. 2 W., Seward Meridian

Aquifer tapped: Bagle Ridge aquifer (Quaternary)

Owner: State of Alaska

Well characteristics: Annulus between 3-in.-diam PVC casing and 6-in,-diam steel casing; depth $200 \mathrm{ft}$, open from 126 to $129 \mathrm{ft}$

Land surface altitude: $516 \mathrm{ft}$ (determined from 1:2,400-scale topographic map).

\section{Well ERS}

Location: NE1/4 NE1/4 NE1/4 NE1/4 Sec. 13, T. 14 N. R. 2 W., Seward Meridian

Aquifer tapped: midvalley aquifer (Quatemary)

Owner: State of Alaska

Well charactoristics: Dismeter 6 in.; depth $268 \mathrm{ft}$; open from 263 to $268 \mathrm{ft}$

Land surface altitude: $516 \mathrm{ft}$ (determined from 1:2,400-scale topographic map).

Water-level data collected from closely spaced wells constructed at different depths in the midvalley aquifer have shown that water-level differences within the aquifer are typically small (less than a few feet) with both upward and dowaward hydraulic gradients. Thus, the potentiometric surface of the aquifer (shoet 4) was constructed by using data collected from a Pebruary-June 1983 survey of water levels in local wells and elevation information where the squifer crops out. Water-level data reported by drillers at the time of well construction were also used, but only to guide contour drawing in areas of sparse 1983 data. Examination of figure 5 and sheet 4 shows that water-level changes that occurred in the aquifer during the 1983 waterlevel aurvey wero small compared to the scale and contour interval of the potentiometric surface map.

Sporadic water-level data collected at two wells tapping the midvalley aquifer (sheet 3 ; table 4 ) indicate that water-level declines of about $10 \mathrm{ft}$ occurred in the northcentral part of the aquifer before 1983, A comparison of water-level measurements made in 12 wells during 1983 with levele reported at the time of well construction (which ranged from 1962 to 1978) showed that the median apparent water-level change was $-1.1 \mathrm{ft}$ (1983 water levels were lower). Most of these water-level measurements were mado in the southwest part of the aquifer.
The midvalley aquifer is recharged from local precipitation and stowmelt through overlying aquifers and leaky confining urits. Also, Meadow Creek is a probable source of recharge for aquifers in the area.

On July 2, 1974 the U.S. Geological Survey (Scully and others, 1978, p. 102) made two streamflow measurements on the lower reaches of Meadow Creek. They observed discharges of $6.87 \mathrm{cfs} 200 \mathrm{ft}$ upstream from the mouth of Meadow Creek, and $8.75 \mathrm{cfs} 1.5$ miles above the mouth near the apex of the Meadow Creek alluvial fan. This suggests a net loss of $1.88 \mathrm{cfs}$ or $1.2 \mathrm{mgd}$ by the stream along its lower reaches,

\section{Eagleridge Aquifer}

The Bagleridge aquifer is informally named for the overlying Bagleridge Subdivision (sheet 4) and consists of glaciofluvial deposits shown in sheet 2 , and sandy and gravelly sediments that are laterally equivalent (umit Qaler, sheet 1). The Bagleridge aquifer was described as the "upper" aquifer by Munter (1984). Structure contours of the top of the Eagleridge aquifer (sheet 4) shows that it has a fan-like upper surface near Meadow Creek and a relatively flat profile over much of the midvaliey area, suggesting that sediments composing the aquifer were derived 


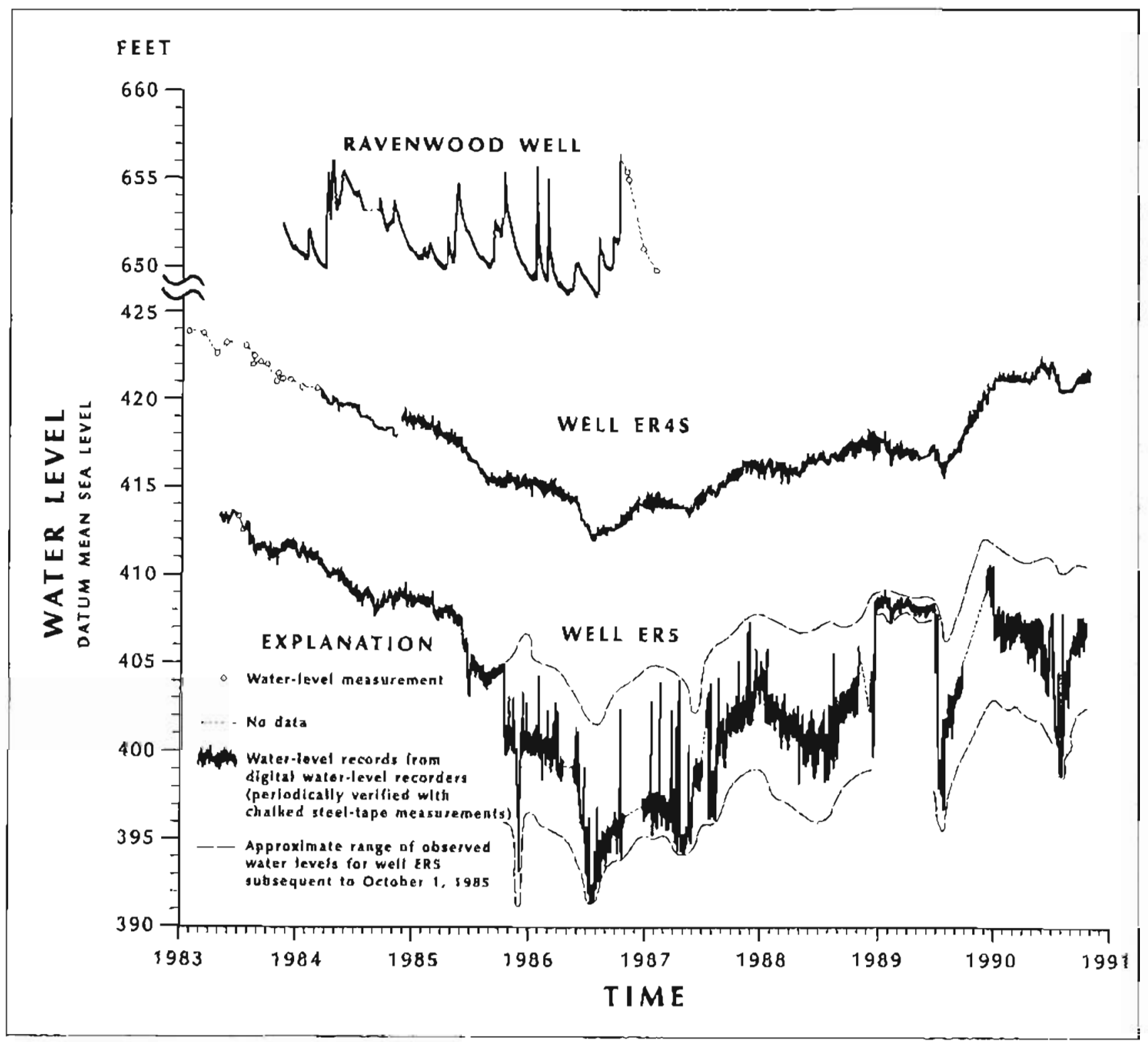

Figure 5. Water-level data collected at three wells in Eagle River.

from a source area north of the aquifer. Possible channellike erosional features are evident on the upper surface of the aquifer. Along its western and southern edges, the equifer is near land surface and is erosionally truncated. Although most wells that tap the Eagleridge aquifer are not drilled to the bottom of the aquifer, available data suggest that the aquifer is 10 to $43 \mathrm{ft}$ thick in most places. In the northeentral part of the aquifer near Meadow Creek, the sand and gravel deposits thicken to abourt $80 \mathrm{ft}$ but the upper parts are unsaturated. Reported yields of wells tapping the Eagleridge aquifer range from 2 to $240 \mathrm{gal} / \mathrm{min}$, with a median and mode of $10 \mathrm{gal} / \mathrm{min}$. Three calculated transmissivity values for the aquifer range from 200 to $2,600 \mathrm{ft}^{2} / \mathrm{day}$ (table 1). Two public water-supply systems obtain water from the Eagleridge aquifer (able 2).
The potentiometric surface of the Eagleridge aquifer was defined measuring static-water levels in 58 domestic wells in 1983 (sheet 4). Data reported by drillers were used to guide the drawing of contours in areas of sparse data. The potentiometric surface illustrates that ground-water flow in the aquifer is toward the southwest.

An observation well (well ER4S, sheets 1 and 3; table 3) tapping the Eagleridge aquifer installed in late 1982 serves to identify recent water-level trends. The hydrograph (fig. 5) shows that water levels declined in a pattern similar to well ER5, although the magnitude of declines was less and water levels did not exhibit large daily fluctuations. Water levels declined about $11 \mathrm{ft}$ from early 1983 to mid-1986, and increased about $11 \mathrm{ft}$ from mid-1986 to late 1990. A comparison of 53 water-level 


\begin{tabular}{|c|c|c|c|c|}
\hline $\begin{array}{c}\text { Well } \\
\text { identifiar }\end{array}$ & $\begin{array}{c}\text { Date of } \\
\text { measurement }\end{array}$ & $\begin{array}{c}\text { Static water } \\
\text { level } \\
\text { (At) } \\
\end{array}$ & $\begin{array}{l}\text { Well opening } \\
\text { interval(s)e } \\
(\mathrm{t})\end{array}$ & Source \\
\hline $2-15$ & $03 / 09 / 70$ & 176.2 & $240-268$ & R.W. Kranich, written commun., 1970 \\
\hline $2-15$ & $11 / 15 / 78$ & 178.0 & $240-268$ & W.C. Ellis, written commun., 1978 \\
\hline $2-15$ & $03 / 31 / 83$ & 186.6 & $240-268$ & R.D. Allely, DGGS \\
\hline $1-76$ & $10 / 04 / 78$ & 215.3 & $263-283,336-342$ & R \& M (1979); Smith and Robertson (1983) \\
\hline $1-76$ & $09 / 28 / 83$ & 224.9 & $263-283$ & \\
\hline $1-76$ & $10 / 18 / 83$ & 225.0 & $263-283$ & Smith and Robertson (1983) \\
\hline
\end{tabular}

measurements made during 1983 with those reported at the time of well construction (1957 to 1981) shows that the median increase of water levels was $7.3 \mathrm{ft}$. Most water-level measurements were made in the eastem part of the Eagleridge aquifer (sheet 4).

\section{Hylen Crest Aquifer}

The Hylen Crest aquifer, identified solely by using subsurface data, occurs east of Eagle River Lane in the midvalley area (sheets 1 and 3 ). This aquifer is informally named for Hylen Crest subdivision (sheet 4) which partially overlies it and is served by a public water system that relies on two wells tapping the aquifer. These are well 2-24 (346 $\mathrm{ft}$ deep), which has a reported yield of $182 \mathrm{gal} / \mathrm{min}$, and well 1-24 (308 $\mathrm{ft}$ deep), which has a reportod yield of $61 \mathrm{gal} / \mathrm{min}$. A single calculated transmissivity value for the aquifer is $47 \mathrm{ft}^{2} / \mathrm{day}$ (table 1). Two public watersupply systems obtain water from the Hylen Crest aquifer (table 2).

The top of Hylen Crest aquifer occurs 200-300 ft below land surface in most places. The aquifer is locally up to $30 \mathrm{ft}$ thick, but silty zones are common. Reported yields range from 3 to $182 \mathrm{gal} / \mathrm{min}$, with a median of $7 \mathrm{ga} / \mathrm{min}$. The shape and position of the aquifer suggest that sediments composing the aquifer may have been deposited as a proglacial fan or delta from westerly or easterly glacial sources. As described later, a westerly glacial source is most likely.

The general configuration of the potentiometric surface of the Hylen Crest aquifer (sheet 4 ) is described by using relatively few water-level data. Ground water is recharged to the aquifer through overlying glacial drift and is discharged to wells, deeper deposits, and wetland areas near the Eagle River. A comparison of six water-level measurements made during 1983 and 1984 with measurements made at the time of well construction (1972 to 1983) showed that the median increase of water levels was $5.8 \mathrm{ft}$. Examination of geologic and water-level data indicates that the Hylen Crest aquifer is separated from overlying and underlying aquifers by 60 to $120 \mathrm{ft}$ of lowpermeability fine-grained glacial sediment.

\section{Ravenwood Aquifer}

The Ravenwood aquifer, located near Eagle River Lane in the eastern part of the midvalley area, is informally named for Ravenwood Elementary School (sheet 4). The aquifer is identified solely with subsurface data, alchough seeps and a spring occur at the south edge of the aquifer, where it is inferred to discharge through a thin soil and vegetative mantle. Well RA V (sheets 1 and 3), also known as Ravenwood School well 1, taps the aquifer and has a depth of $44 \mathrm{ft}$. The well was never used as a public supply well because of insufficient yield, but was used as a water-level observation well (fig. 5; table 3). Analysis of well-log data indicates that the aquifer is composed principally of sand and gravel and is confined both above and below by less permeable till. Most well logs show an aquifer thickness of 2 to $12 \mathrm{ft}$. Reported well yields range from 1.5 to $30 \mathrm{gal} / \mathrm{min}$, with a median of $7 \mathrm{gal} / \mathrm{min}$. A single calculated transwissivity value for the aquifer is $40 \mathrm{ft}^{2} /$ day (table 1). The depth to the top of the aquifer varies from about $130 \mathrm{ft}$ in the north to near zero feet in the south, where the aquifer appears to be erosionally truncated. The aquifer is recharged by percolation of precipitation and snowmelt through the overlying confining unit. The shape and location of the aquifer suggest that the aquifer materials were deposited as an eastward prograding alluvial fan from a westerly glacial source.

The potentiometric surface of the Ravenwood aquifer (sheel 4) is about 100 to $300 \mathrm{ft}$ higher than that of the Hylen 
Crest aquifer, and 220 to $250 \mathrm{ft}$ higher than that of the Eagleridge aquifer. Ground water in the Ravenwood aquifer flows generally to the south through the aquifer and seeps vertically downward to the underlying Hylen Crest and Eagleridge aquifers through leaky confining units. Water-level records from an observation well tapping the Ravenwood aquifer (fig. 5) show a fluctuation range of about $8.5 \mathrm{ft}$, but no significant trend over the 3-yr period. Mid- to late-wiater increases in water level correlate with brief mid-winter thaw periods accompanied by precipitation events (Munter, 1986). This indicates that relatively rapid recharge to the Ravenwood aquifer accurs, even through surficially frozen soils.

A comparison of 20 water-level measurements made during 1983 with measurements reported at the time of well construction (1965 to 1983) shows the median increase in water level to be $9.0 \mathrm{ft}$.

\section{ORIGIN OF GLACIAL DEPOSITS IN THE MIDVALLEY AREA}

As previously described, the Fagleridge aquifer is considered to be composed of advance outwash deposited during the late stade of the Naptowne Glaciation of Late Wisconsinan age. Comparison of sheet 4 shows that the aquifer extends north and east from its outcrops to areas where the Ravenwood and Hylen Crest aquifers and intervening deposits overlie it. These upper two aquifers and the overlying and underlying till are therefore inferred to be part of the Elmendorf moraine deposits that lie directly over the Eagleridge aquifer. The total thickness of sediment overlying the Eagleridge aquifer ranges up to about $400 \mathrm{ft}$.

Schmoll and others (1980) mapped the eastem extent of Elmendorf-equivaleat ground moraine (unit Qmg) to the eastem limit of the Bagleridge aquifer (sec. 17, T. 14 N., R. 1 W., SM). Confirmation that deposits from the KnikMatanuska glacial lobe extended to that location was provided by identification of a cobble-sized clast of pyroxenite in an exposure of glaciofluvial materials localed near Eagle River Lane. Pyroxenite is not known to occur farther up the Eagle River Valley (R.G. Updike, Alaska Division of Geological \& Geophysical Surveys, oral commun, 1985), but does occur in the Krik Arm drainage (Clark, 1972b; Rose, 1966).

The deposits comprising the Ravenwood and Hylen Crest aquifers are interpreted to have been deposited as a result of minor fluctuations in the position of the glacial ice front during the late stade of the Naptowne Glaciation that produced the Elmendorf morajae. Deposition of aquifer materials in alluvial fans or fan-delta complexes is attributed to the discharge of ice-marginal streams flowing along the Chugach Mountain front from the north into the ice-free Eagle River valley. The existence of ice-marginal streams has previously been postulated to explain the modern presence of large channels along the Chugach Mountain front near Eagle River (Yehle and Schmoll, 1989).

The interpreted geologic history presented in this report is based in part on geologic mapping by Schmoll and others (1980) rather than on recently revised mapping (Yeble and Schmoll, 1989) that shows Dishno Pond moraine deposits overlying the Ravenwood, Hylen Crest, and Eagleridge aquifers. The Dishno Pond moraine is in ferred (Schmoll and Yehle, 1986) to have been deposited as a result of a glacial advance of the Knik-Matanuska ice lobe that preceded the advance that produced the Elmendorf moraine. The Dishno Pond moraine interpretation of Yehle and Schmoll (1989) is not used in this report because it is not consistent with the stratigraphic correlations described herein.

\section{INTERPRETATION OF WATER-LEVEL TRENDS IN THE MIDVALLEY AREA}

Water levels in confined aquifers in the midvalley area are influenced mainly by ground water pumpage and variations in natural recharge. The midvalley and Eagleridge aquifers, for example, exbibit a limited amount of hydraulic communication as evidenced by a 24 -hr equifer test performed in the midvalley aquifer. Well $2-4$ (sheet 3, table 1) was pumped at $295 \mathrm{gal} / \mathrm{min}$, and $2 \mathrm{ft}$ of drawdown was observed in wells 1-4 and 1-5 (sheet 3 , table 1), which were completed in the Eagleridge aquifer nearby (F. Damron, CH2M Hill, written commun. , 1983). The water-level record at well ER5, as previously described, exhibits short-term fluctuations in response to pumping at well 2-4. Long-term changes in pumping are also related to changes in water levels. Ground-water punapage patterns have changed in recent years as a result of population increases and importation of surface-water supplies from Ship Creek and Eklutna Lake. Examination of water-use patterns is necessary to obtain an understanding of the causes of long-term ground-water level changes.

\section{WATER-USE DATA}

Munter (1984) estimated an average 1983 Eagle River per-capita water use value of $120 \mathrm{gal}$ per person per day, primarily based on water use data from residential neighborhoods. Light commercial development in part of the study area may increase the estimate of areawide percapita use to 130 to $140 \mathrm{gg} /$ / day and is comparable to Municipality of Anchorage values of $150 \mathrm{gal} / \mathrm{person} / \mathrm{day}$ used for planning (Municipality of Anchorage, 1983). Using an average per-capite figure of $135 \mathrm{gal} / \mathrm{day}$ and a 1988 population figure of 14,106 in the midvalley area (Muricipality of Anchorage, 1989), total water use is estimated to be 1.9 million gal/day. 
About 46 percent of midvalley's total water demand is supplied by AWWU, 17 percent by Norfolk and Eklutna Utilities, and 37 percent by individual residential wells and a variety of small to midsized privately owned public water-8upply systems using wells (fig. 6). Locstions of all known active class $A$ and class B public-water-supply wells are shown in sheet 3 . Definitions of class $A$, class $B$ and class C systems are given by Alaska Department of Environmental Conservation (1982).

Until 1986, four of the mast beavily pumped public water-supply systems in the midvalley area (Norfolk Utilities, Eagle River Heights North-AWWU, Eklutaa Utilities, and Eagle Crest-AWWU), were located in the central part of the region underlain by confined aquifers. Most of the water pumped was extracted from the midvalley and Eagleridge aquifers.

Before 1983, almost no water-use data were collected in Eagle River. Data collected between 1983 and 1987 from these four systems are shown in figure 7. Figure 7 illustrates the rapid increase in water use that occurred between 1983 and 1986, and the decrease in pumpage that occurred as a result of AWWU's switch to surface-water sources between 1986 and 1988.

\section{PRECIPITATION TRENDS}

The only long-term precipitation data available near Eagle River are collected at Anchorage International Airport, $17 \mathrm{mi}$ southwest of the study area. Although local variations in precipitation occur as a result of orographic and geographic differences, long-term trends observed at the aiport are probably similar to trends at Bagle River. Precipitation data (fig. 8) show that the years 1968 to 1978 had average or below-average precipitation and that 1979 to 1982 were substantially above average. A record amount of precipitation fell in Anchorage in 1989.

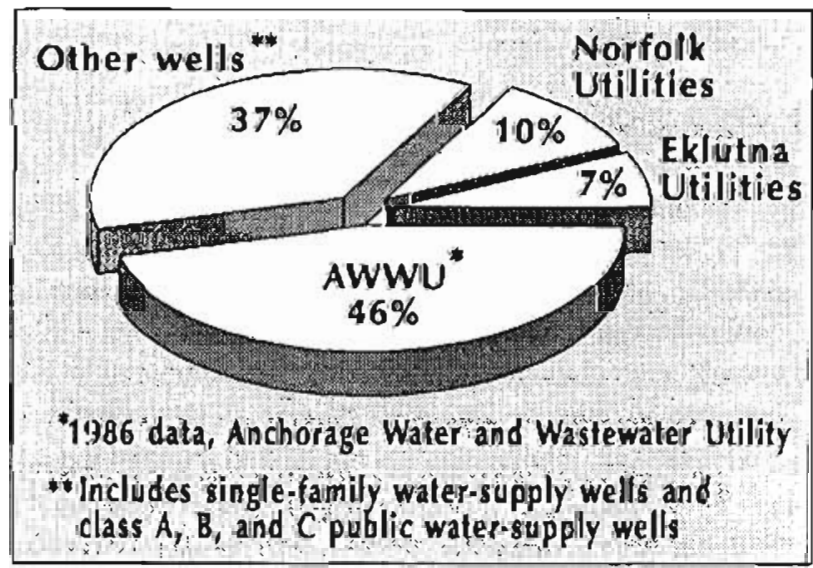

Figure 6. Estimated and reported water use in the midvalley area, 1988. Total estimate, $1.9 \mathrm{mil} / \mathrm{gal} / \mathrm{day}$.

\section{CORRELATION OF WATER-LEVEL, WATER- USE, AND PRECIPITATION DATA}

About two-thirds of the private domestic wells whose water levels were maasured during 1983 were drilled between 1975 and 1978. Water levels reported by drillers at the time these wells were constructed were probably near or below average as a result of several years of average or below-average precipitation prior to their construction. Measurements made during 1983 closely followed 4 yr of above-average precipitation, resulting in higher measured water levels except where influenced by pumping from public-supply wells. Water levels observed in the Ravenwood, Hylen Crest, and Eagleridge aquifers during 1983 were generally higher than those reported by well drillers. Ravenwood aquifer, the shallowest, showed the largest median increase in water levels. In the midvalley aquifer, which is more heavily pumped than the other three, increases in water-level elevations that could be expected as a result of increased precipitation appear to have been offet by drawdowns caused by pumping; this resulted in an apparent minor average drop $(1.1 \mathrm{ft})$ in midvalley pre-1983 water levels. Pumping of ground water does not appear to have had any significant effect on water Jevels in the Ravenwood aquifer.

The rise in water levels observed in the Eagleridge and midvalley aquifers from 1986 to 1988 (fig. 5) is probably the results of a major reduction in ground-water pumpage that occurred during that period (sheet 1). The rise in water levels observed during 1989 is likely a result, in part at least, of the unusually large amount of precipitation that fell in 1989.

\section{WELL FAILURES IN THE MIDVAKLEY AREA}

Aside from well problems associated with the lowpermeability bedrock aquifer described previously, six wells tapping confined sand-and-gravel aquifers in the southwest part of section 12 of T. 12 N., R. 2 W. were reported to have failed during March and April 1986 (Munter, 1986). These wells had original reported yields of 5 to $10 \mathrm{gal} / \mathrm{min}$ and failed when static-water levels dropped to within a few feet of the well bottoms and exposed the submersible pumps. This loweriag of staticwater levels was caused by an areawide lowering of potentiometric surfaces of the Eagleridge and midvalley aquifers (fig. 5), which in turn was primarily attributed to pumping from those confined aquifers by private and public water-supply wells. Five of the six walls originally tapped the Engleridge aquifer, and one tapped the upper part of the midvalley aquifer. All six wells were deepened or redrilled into the midvalley aquifer and obtained reported yields of 10 to $25 \mathrm{gal} / \mathrm{min}$. The new wells are an 


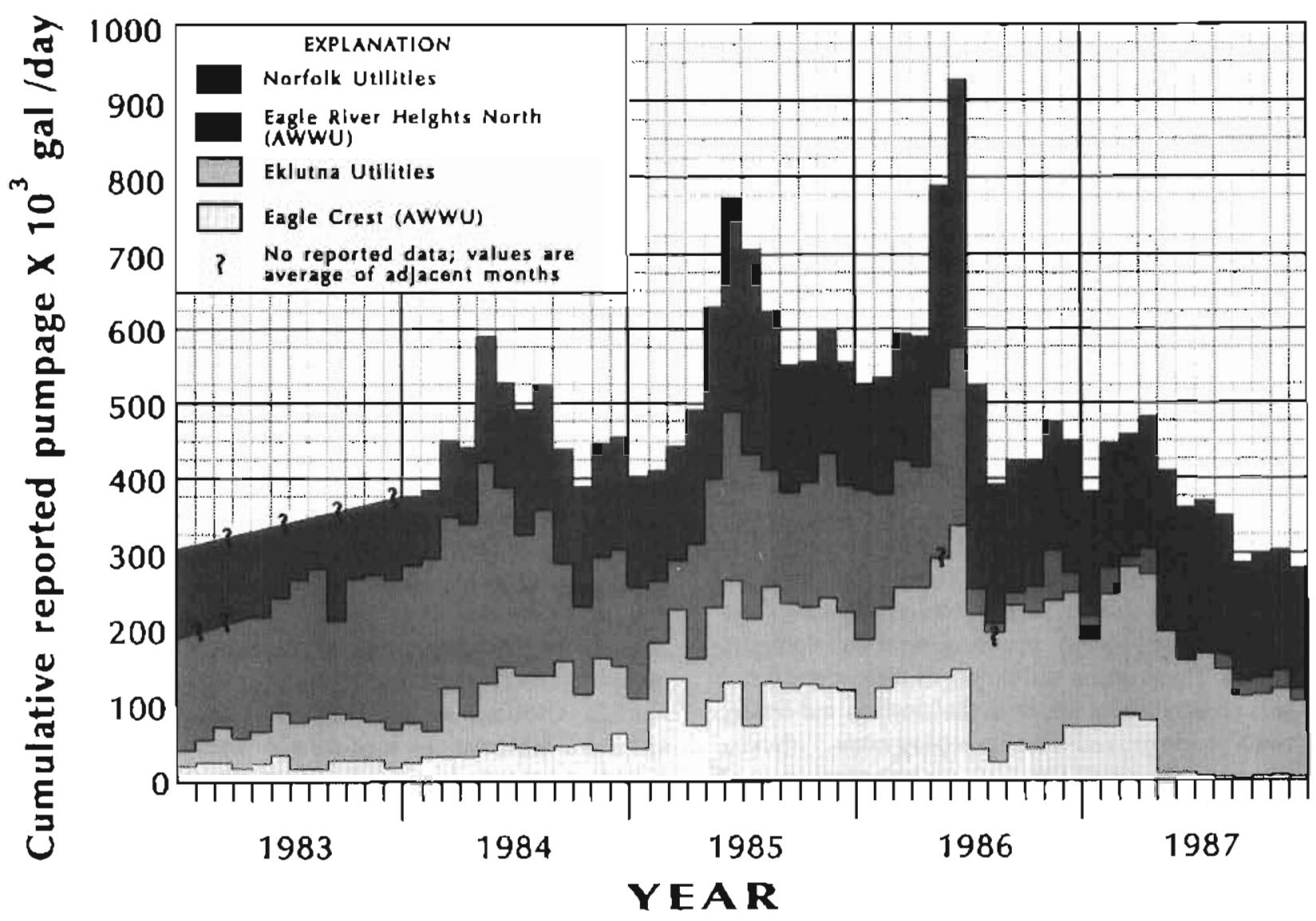

Figure 7. Water-use dasa for four major users of confined aquifers in Eagle River, 1983-87.

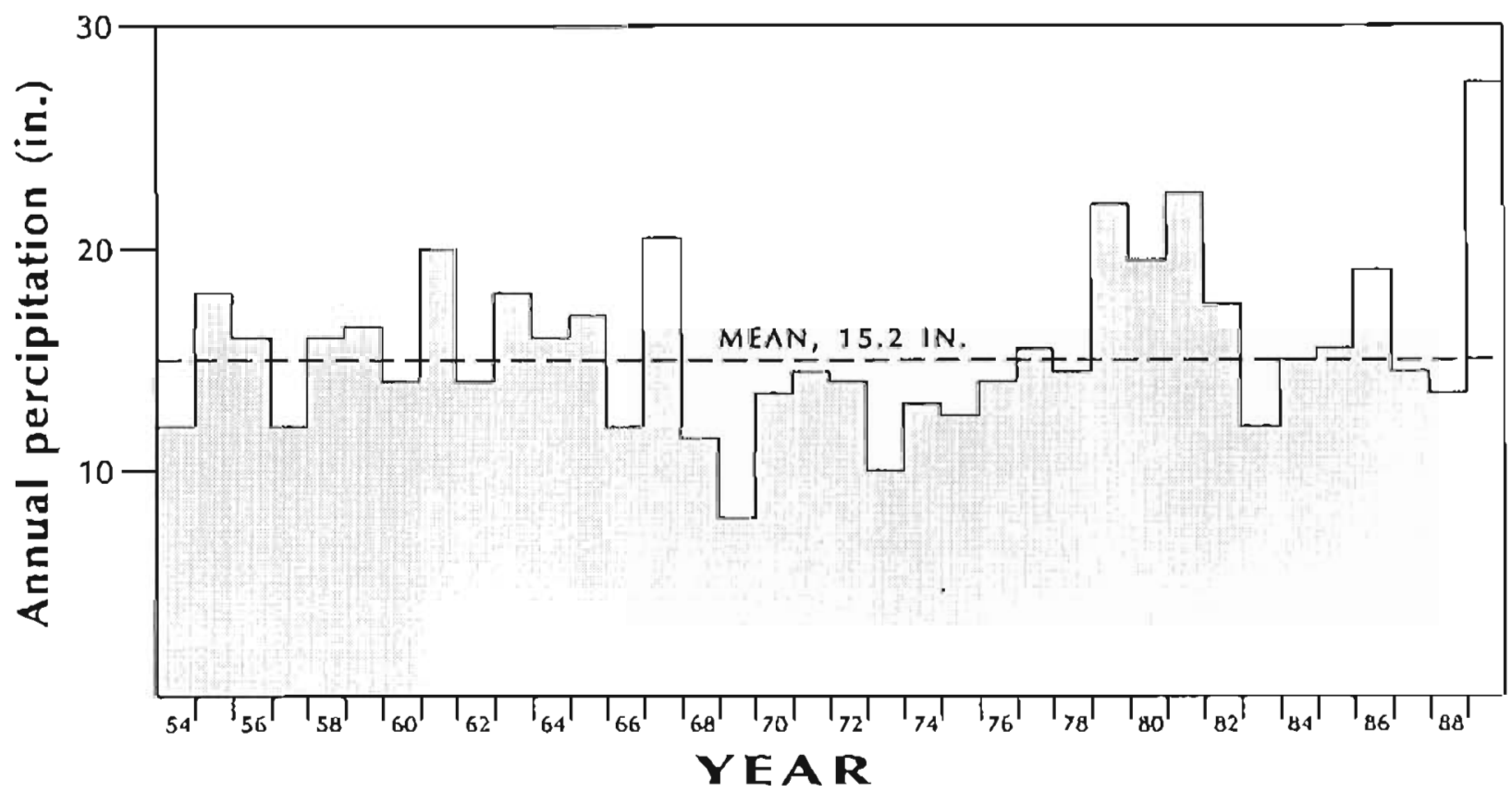

Figure 8. Annual precipitation at Anchorage Weasher Service Meteorological Office - Airport. 
average of $62 \mathrm{ft}$ deeper than the old wells. The potentiometric surface of the midvalley and Eagleridge aquifers reached their historic lows in early to mid-1986, coincident with the occurrence of the well failures (fig. 5). No new failures of wells tapping these aquifers are known to have occurred since mid-1986.

\section{SUMMARY AND CONCLUSIONS}

Ground-water supplies are available throughout the Eagle River area from nonlithified and sedimentary-and metamorphic-rock aquifers. In the upper Eagle River valley, large well yields may be available only from sidevalley alluvial deposits. In the midvalley area, ground water is obtained from shallow glacioalluvial, undifferentiated glacial and glaciofluvial, bedrock, and confined sand-and-gravel aquifers. Water levels declined before July 1986 in western parts of two confined aquifers (midvalley and Eagleridge), resulting in several domestic well failures. The location and timing of these water-level declines is closely associated with the location and timing of bighest historic ground-water pumping rates. Pumping by private and public well owners is the principal cause of failure of wells tapping confined aquifers. Well-yield problems in the bedrock aquifer are caused by the low permeability of the aquifer. Since 1986, total well-water use has decreased, water levels in the two largest confined aquifers (midvalley and Eagleridge) have risen, and no oew well failures are known to have occurred in the area where confined aquifers are used. Significant water-level declines and well failures have not been observed in wells tapping the Ravenwood or Hylen Crest confined aquifers, where large-scale public-supply well development has not occurred, Water levels in these aquifers appear to be relatively unaffected by pumping from existing residential and public-supply wells in the area.

Although surface water supplies from outside the Eagle Rjver area have replaced and augmented local ground water in areas served by AWWU to a large extent, substantial areas of residential development continue to be served by singlefamily and small public-water systems. In most of these areas, ground-water resources are likely to remain adequate for local water-supply requirements. However, local watersupply problems caused by the low-permeability bedrock aquifer may persist in some areas.

\section{ACKNOWLEDGMENTS}

This project was principally funded by the State of Alaska general fund during fiscal years 1982-93 as part of the cooperative AWARE (Alaska Water Resource Evaluation) program with the U.S. Geological Survey. We thank numerous agencies and individuals for contributions of data, which made the study feasible. In particular, we thank area drillers for recording and providing useful information on their well logs; Alaska Division of Land and Water Management, Alaska Department of Environmental Conservation, and Municipality of Anchorage On-site Services for providing copies of well logs; water suppliers, including Anchorage Water and Wastewater Utilities, Norfolk Utilities, and Eklutna Utilities, for supplying water-use information; area land owners and managers including Ekklutna, Inc., the Anchorage School District, the Alaska Department of Transportation and Public Facilities, Carmel McIntyre, and a large number of homeowners for allowing access to their properties and wells; and engineering firms and their staffs, including Floyd Damron of $\mathrm{CH} 2 \mathrm{M}$ Hill and Wayne McFadden, formerly of Dowl Engineers, for providing engineering information concerning public supply wells. The patience of the Ground Water Site Inventory unit of the USGS is appreciated for near-contiouous maintenance of the database for this study. Larry Dearborn initiated the project and provided useful insights, and Randall G. Updike and Cathy Ulery provided help with the local geology. Finally, we thank Gary Prokosch of DLWM for his skillful management of water-rights problems related to this investigation. Updike, Richard Noll, and Roy Glass provided constructive and thoughtful reviews of the manuscript. 


\section{REFERENCES CITED}

Alaska Department of Environmental Conservation, 1982, Drinking Water Regulations: Juneau, Alaska Department of Eavironmental Conservation, 20 p.

CH2M Hill, 1981, Eagle River water resources study, task 1 - well drilling program: Unpublished report prepared for the Municipality of Anchorage, $49 \mathrm{p}$.

Clark, S.H.B., 1972a, Reconnaissance bedrock geologic map of the Chugach Mountains near Anchorage, Alaska: U.S. Geological Survey Miscellaneous Field Studies Map MP-350, 1 sheet, scale 1:250,000.

1972b, The Wolverine Complex, a newly discovered layered ultramafic body in the western Chugach Mountains, Alaska: U.S. Geological Survey Openfile Report 522, $10 \mathrm{p}$.

1973, The McHugh Complex of south-central A laska: U.S. Geological Survey Bulletin 1372-D, 10 p.

Cooper, H.H., and Jacob, C.E., 1946, A generalized graphical method for evaluating formational constants and summarizing well field history: American Geophysical Union Transactions, v. 27, p. 526-634.

Dearborn, L.L., 1977, Ground-water investigation at the alluvial fan of the South Fork Eagle River, Anchorage, Alaska - Results of test drilling, 1976: U.S. Geological Survey Open-file Report 77-493, 9 p.

Dearborn, L.L., and Schaefer, D.H., 1981, Surficial geophysical data for two cross-valley lines in the middle Eagle River valley, Alaska: U.S. Geological Survey Open-file Report 80-2000, 14 p.

Deeter, G.B., and George, R.S., 1982, Hydrologic data from test wells and low-flow investigations in the middle reach of the Eagle River valley, Alaska, 1980-81: U.S. Geological Survey Open-file Report $82-363,13 \mathrm{p}$.

H4M Corporation, 1986, Somerset Terrace Estates, groundwater exploration and evaluation: Unpublished report prepared for Knakanen Corporation, Anchorage, Alaska, 8 p. plus appendixes.

Johnson, Paula, 1979, Hydrogeologic data for the Eagle River-Chugiak area, Alaska: U.S. Geological Survey Water Resources Investigation 79-59, 17 p.

Jones, D.L., and Silberling, N.J., 1979, Mesozoic stratigraphy-the key to tectonic analysis of southern and central Aleska: U.S. Geological Survey Open-file Report 79-1200, 39 p.

Karlstrom, T.N.V., 1964, Quatemary geology of the Kenai lowland and glacial bistory of the Cook Inlet region, Alaska: U.S. Geological Survey Professional Paper 443, 69 p.

MacKevett, E.M., and Plafker, George, 1974, The Border Ranges fault in south-central Alaska: U.S. Geological Survey Journal of Research, v. 2, no. 3, p. 323-329.
Marsters, Beverly, Spiker, Elliot, and Rubin, Meyer, 1969, U.S. Geological Survey radiocarbon dates X: Radiocarbon, v. 11, no. 1, p. 210-227.

Miller, R.D., and Dobrovolny, Emest, 1959, Surficial geology of Anchorage and vicinity, Alaska: U.S. Goological Survey Bulletin 1093, 128 p., 6 shets in pocket.

Muracipality of Anchorage, 1983, Task III, preliminary water supply master plan update: Unpublished report prepared for Anchorage Water and Wastewater Utitlity by James M. Montgomery, Consulting Engineers, Inc., in association with QUADRA Engineering, Inc., Ott Water Engineers, Inc., and Sverdrup/SPCM, unpaginated.

1989, 1988 Anchorage population and bousing profile, part 3: quarter section grid summaries: Anchorage Department of Economic Development and Planning, unpaginated.

Munter, J.A., 1984, Ground-water occurrence in Eagle River, Alaska: Alaska Division of Geological \& Geophysical Surveys Report of Investigations 84-21, 15 p.

1986, Evidence of groundwater recharge through frozen soils at Anchoragc, Alaska, in Kane, D.L., ed., Cold Regions Hydrology Symposium: Proceedings, American Water Resources Association, Bethesds, Maryland, p. 245-252.

1989, Well failures in southwest Eagle River, Alaska: Alaska Division of Geological \& Geophysical Surveys Report of Investigations 87-14, 6 p.

Munter, J.A., and Dearborn, L.L., 1984, Evaluation of a shallow sand-and-gravel aquifer at Eagle River, Alaska, in Short Notes on Alaskan Geology, 1982-83: Alaska Division of Geological \& Geophysical Surveys Professional Report 86, p. 13-18.

Munter, J.A., and Maynard, D.L., 1987, Extent of groundwater contamination in Alaska: Alaska Division of Geological \& Geophysical Surveys Report of Investigations 87-16, $17 \mathrm{p}$.

Munter, J.A., and Prokosch, G.J., 1985, Recognition and resolution of Eagle River's ground-water conflicts: Roles of data and water rights, in Dwight, L.P., Chairman, Resolving Alaska's water resources conflicts: Proceedings, Alaska section, American Water Resources Association, Institute of Water Resources/ Engineering Experiment Station, University of AlaskaFairbanks, Report IWR-108, p. 167-175.

Neuman, S.P., 1974, Effect of partial penetration on flow in unconfined aquifers considering delayed gravity response: Water Resources Research, v، 10, no. 2, p. 303-312.

Petrik, W. A., 1986, Residential well development in a low permeability bedrock flow system, in Kane, D.L., 
ed., Cold Regions Hydrology Symposium: Proceedings, American Water Resources Association, Bethesda, Maryland, p. 253-262.

1990, Summary of water-use data in Alaska, 1986: Alaska Division of Geological \& Geophysical Surveys Report of Investigations 90-2, $68 \mathrm{p}$.

1991a, Summary of water-use data in A laska, 1987:

Alaska Division of Geological \& Geophysical Surveys Report of Investigations in publications.

1991b, Suramary of water-use data in Alaska, 1986: Alaska Division of Geological \& Geophysical Surveys Report of Investigations, in publication.

Plafker, George, and Campbell, R.B., 1978, The Border Ranges fault in the Saint Elias Mountains, in Johnson, K.M., and Williams, J.R., eds., The United States Geological Survey in Alaska-accomplishments during 1978: U.S. Geological Survey Circular 804-B, p. B102-B104.

R\&M Consultants, Inc., 1979, Eagle River water supply study, Meadow Creek area, Alaska, final report: unpublished report prepared for the Alaska Department of Environmental Conservation, $44 \mathrm{p}$.

Reger, R.D., and Updike, R.G., 1983, Upper Cook Inlet

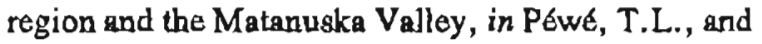
Reger, R.D., eds., Guidebook to permafrost and Quaternary geology along the Ricbardson and Glenn Highways between Fairbanks and Anchorage, Alaska: Alaska Division of Geological \& Geophysical Surveys Guidebook 1, p. 185-263.

Retherford Associates, and Adams, Corthell, Lee, Wince, and Associates, 1966, Preliminary engineering report, Eagle River project, Anchorage, Alaska: Unpublished report prepared for City of Anchorage, Municipal Light and Power Department, $11 \mathrm{p}$.

Rose, A.W., 1966, Geology of chromite-bearing ultramafic rocks near Ekkutna, Anchorage Quadrangle, Alaska: Alaska Division of Mines and Minerals Geologic Report 18, $20 \mathrm{p}$.

Schmoll, H.R., Dobrovolny, Emest, and Oardner, C.A., 1980, Preliminary geologic map of the middle part of the Bagle River valley, Municipality of Anchorage, Alaska: U.S. Geological Survey Open-file Report 80-890, 12 p., 1 sheet, scale 1:25,000.

Schmoll, H.R., Dobrovolny, Emest, and Zenone, Chester, 1971, Generalized geologic map of the Eagle RiverBirchwood area, Greater Anchorage Aren Borough, Alaska: U.S. Geological Survey Open-file Map 71-248, 1 sheet, scale 1:63,360.

Schmoll, H. R., and Yehle, L.A., 1986, Pleistocene glaciation of the upper Cook Inlet basin, in Hamilton, T.D., Reed, K.M., and Thorson, R.M., eds., Glaciation in
Alaska - the geologic record: Anchorage, Alaska Geological Society, p. 193-218.

Schmoll, H.R., Yehle, L.A., Gardner, C.A., and Odum, J.K, 1984, Guide to the surficial geology and glacial stratigraphy in the upper Cook Inlet basin: Anchorage, Alaska Geological Saciety guidebook, 98 p.

Scully, D.R., Leveen, L.R. George, R.S., 1978, Surface water reconds of Cook Inlet basin, Alaska, through September 1975: U.S. Geological Survey Open-file Report 78-498, 102 p.

Smith (Ted) and Robertson \& Associates, 1983, Final report, Eagle River test well-1983, Test well AWWU A-1: Unpublished report prepared for the Municipality of Anchorage Water and Wastewater Utility, $52 \mathrm{p}$.

Theis, C.V., 1935, The relation between the lowering of the piezometric surface and the rate and duration of discharge of a well using ground water storage: American Geophysical Union Transactions, v. 16, p. 519-524.

Tysdal, R.G., and Plafker, George, 1978, Age and continuity of the Valdez Group, southern Alaska, in Sohl, N.F., and Wright, W.B., eds., Changes in stratigraphic nomenclature by the U.S. Geological Survey, 1977: U.S. Geological Survey Bulletin 1457-A, p. A120A124.

Updike, R.G., and Ulery, C.A., 1983, Preliminary geologic map of the Anchorage B-6 NW (Eklutna Lake) Quadrangle, Alaska: Alaska Division of Geological \& Geophysical Surveys Report of Investigations 83-8, 1 sheet, scale 1:10,000.

Wolf, J.A., Hopkins, D.M, and Leopold, E.B., 1966, Tertiary stratigraphy and paleobotany of the Cook Inlet region, Alaska: U.S. Geological Survey Professional Paper 398-A. 29 p.

Yehle, L.A, and Schmoll, H.R., 1988, Surficial geologic map of the Anchorage B-7 soutbeast Quadrangle, Alaska: U.S. Geological Survey Open-file Report 88-381, 19 p., 2 sheets, scale 1:25,000.

1989, Surficial geologic map of the Anchorage B-7 southwest Quadrangle, Alaska: U.S. Geological Survey Open-file Report 89-318, 33 p., scale 1:25,000.

Yehle, L.A., Schmoll, H.R., and Dobrovolny, Emest, 1990, Geologic map of the Aachorage B-8 SE and part of the Anchorage B-8 NE Quadrangles, Alaska: U.S. Geological Survey Open-file Report 90-238, 39 p.. 2 sheets, scale $1: 25,000$.

Zenone, Chester, Schmoll, H.R., and Dobrovolny, Emest, 1974, Geology and ground water for land-use planning in tho Eagle River-Chugiak area, Alaska: U.S. Geological Survey Open-file Report 74-57, 25 p. 


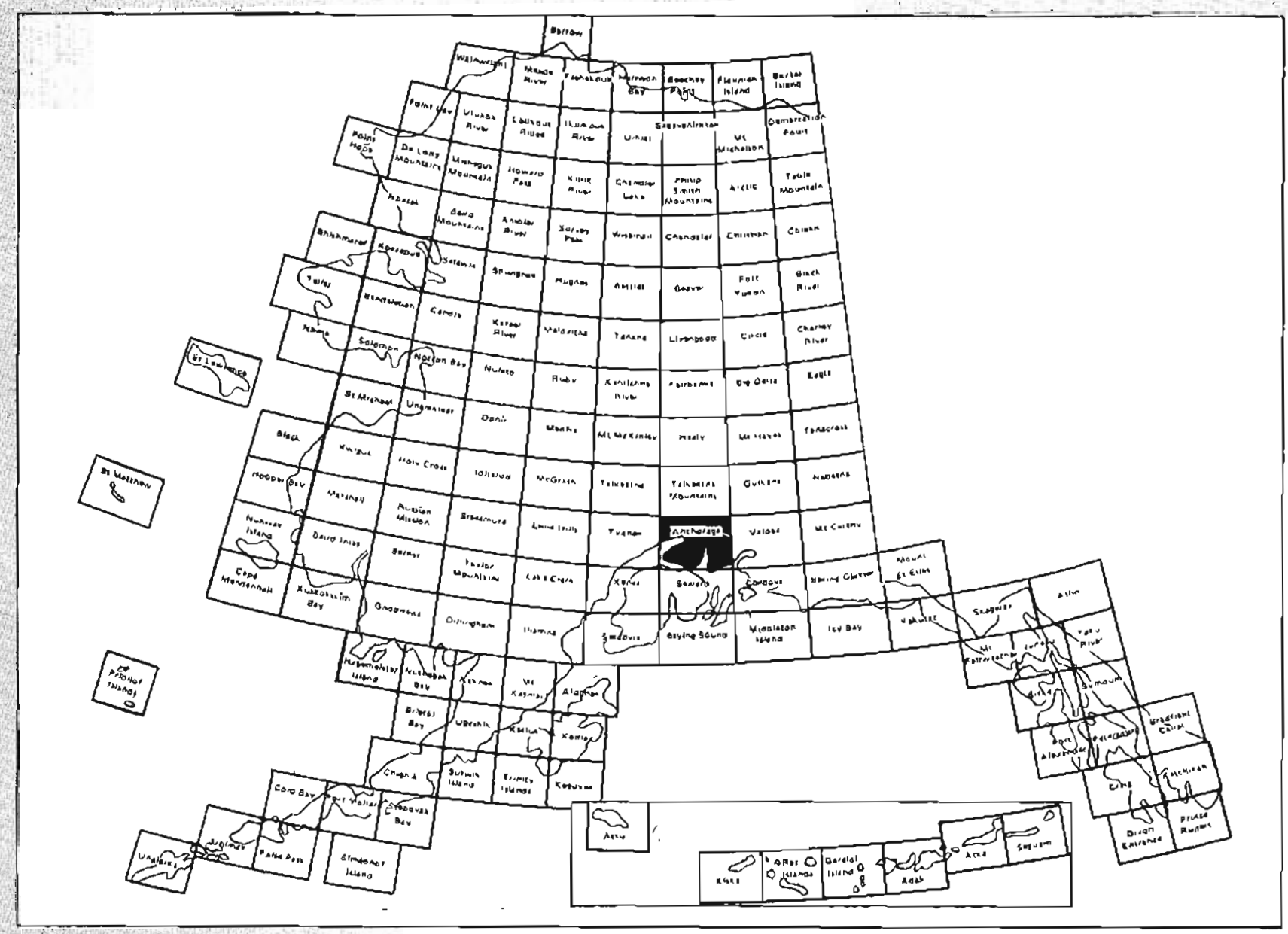

